\title{
1 Reconstruction of ice sheet retreat after the Last Glacial Maximum in
}

\section{Storfjorden, southern Svalbard}

15
* Corresponding author. E-mail address: tni@geus.dk (T. Nielsen)

ABSTRACT

Tove Nielsen $^{\mathrm{a}^{*}}$ and Tine L. Rasmussen ${ }^{\mathrm{b}}$

${ }^{a}$ Geological Survey of Denmark and Greenland (GEUS), Geophysical Department, Øster Voldgade 10,DK-1350 Copenhagen,Denmark(tni@geus.dk)

${ }^{b}$ Centre for Arctic Gas Hydrate, Environment and Climate, Department of Geoscience, UiT - The Arctic University of Norway, N-9037 Tromsø, Norway

Storfjorden is a large north-south trending sound located in the southern part of Svalbard in the northwestern Barents Sea. Presently, several glaciers drain into the northern and western part of Storfjorden. Our study area covers the southern part of the sound, which is divided by a north-south striking basement ridge (the 'Mid-ridge') into a narrow western trough ('Little-Storfjorden') and a broader eastern trough ('Storfjorden'). In the latter, three grounding-zone wedges (GZWs) were discovered in 2005 showing evidence of former grounded ice. Here we confirm the existence and map the extent of the GZWs and reconstruct the pattern and timing of ice retreat in Storfjorden during the deglaciation. The study is based on high-resolution seismic and shallow-acoustic profiles and swath bathymetry, combined with information of lithology and radiocarbon dates from sediment cores. The results show that the three GZWs stretch across the fjord, and that all three are located south of higher basement areas that were upstream of the GZWs and which acted as pinning points during ice retreat. The Mid-ridge imposed a lateral drag to the ice, resulting in an uneven ice 

retreat across the fjord. Outside of the GZWs only a thin cover of glacial deposits was found. The cores were taken in vicinity of the GZWs and all reached till deposits overlain by glacimarine or

30 hemipelagic sediments, enabling dating of the GZWs. Altogether we find that the fjord and

31 basement topography played an important role in the ice retreat. AMS- ${ }^{14} \mathrm{C}$ dates show that the

32 formation of the three GZWs correlate with three well-known atmospheric warming phases (start of

33 Bølling interstadial, Allerød interstadial and Holocene interglacial, respectively) associated with 34 inflows of warm Atlantic water, indicating a strong ocean/climate control on the deglaciation of 35 Storfjorden.

37 Keywords: Storfjorden, Svalbard, deglaciation, high Arctic fjord, Atlantic water, grounding-zone 38 wedge, recessional ridge, LGM ice dome 39 


\section{Introduction}

During the last glacial maximum (LGM) very active ice-streams were present in all the fjords of Svalbard generating cross-shelf troughs along the western and northern Svalbard margin (Ottesen et al., 2007). Detailed reconstructions of ice-stream retreat exist for Isfjorden Trough (Svendsen et al., 1992, 1996), Kongsjorden Trough (e.g., Landvik et al., 2005), and Kveithola Trough (Rüther et al., 2012; Bjarnadottir et al., 2013). Recently, studies of one of the smaller tributary fjords into western Storfjorden has been published (Noormets et al., 2016a,b), as were several studies of glacial seabed features in fjords and sounds from eastern and northern Svalbard (Dowdeswell et al., 2010; Hogan et al., 2010a,b, 2017; Streuff et al., 2017; Flink et al., 2017).

Detailed studies of ice-streams draining the southeastern Svalbard ice sheet are still lacking in the literature. Nevertheless, several papers have suggested that an ice-stream passed southwards through Storfjorden during the LGM and joined the large and composite, west-flowing ice-stream south of Edgeøya that carved the well-studied Storfjorden Trough (e.g., Laberg and Vorren, 1996; Dowdeswell and Siegert, 1999; Dowdeswell et al., 2010; Rebesco et al., 2016) (Fig. 1). Based on 7 glacial sedimentary flow patterns towards east and north, a reconstruction of ice extent over 8 Svalbard concluded that a major independent ice dome existed due north of Storfjorden over the 9 northeastern Svalbard at LGM (Dowdeswell et al., 2010; Hogan et al., 2010). Yet, no ice draining this ice dome towards south was suggested.

1 In 2005, three sedimentary wedges were observed in Storfjorden on a single N-S seismic 62 line (Plassen et al., 2008). These were suggested to be grounding-zone wedges (GZWs) thus 63 indicating the former presence of grounded ice in Storfjorden. Here, we present detailed mapping of 64 these GZWs and reconstructions of the pattern and timing of the ice retreat in Storfjorden using 
65 high-resolution seismic and shallow-acoustic profiles and swath bathymetry, combined with lithological information, fossil faunas, radiocarbon dates and stratigraphy of sediment cores.

\section{Physical setting}

Storfjorden is a c. 130-km long, N-S striking, trumpet-shaped sound in the southeastern Svalbard archipelago, located between $76^{\circ} 30^{\prime}-78^{\circ} 30^{\prime} \mathrm{N}$ and $17^{\circ}-22^{\circ} \mathrm{W}$ (Fig. 1). It is bordered to the west by the island of Spitsbergen and to the east by Edgeøya, Barentsøya and Storfjordbanken (Fig. 1). It connects northward to the northern Barents Sea via two narrow sounds, and opens to the E-W striking Storfjorden Trough in the south at c. $76.30^{\circ}$ N. Storfjorden is bounded by wide shallow shelf areas of about $40 \mathrm{~m}$ water depth to the north and east. The present study focuses on the southern deeper part (Fig. 1). This wider, embayment-like southern part of Storfjorden is divided by a north-south striking basement ridge (here called the 'Mid-ridge') into a narrow western trough (here called 'Little-Storfjorden') and a broader eastern trough (here called 'Storfjorden').

The trough of Storfjorden contains three basins separated by transverse, east-west striking bathymetric highs, here termed the inner, middle and outer high from north to south (Fig. 1). Warm Atlantic surface water derived from the West Spitsbergen Current flows into Storfjorden along its eastern margin (Fig. 2). The Atlantic water occasionally crosses the middle high and enters the two inner basins to the east (Lydersen et al., 2004). Arctic surface water of the East Spitsbergen Current enters Storfjorden via the two passages in the north flowing southwards along western Storfjorden and continues northward along the west Spitsbergen coast as the coastal current (Fig. 2). Brine formation takes place in Storfjorden behind the middle high. This dense, cold water eventually overflows the middle high and continues southwards into Storfjorden Trough. 


\section{列}

Depending on its density, the brine may reach deeper waters of the slope off Svalbard (e.g., Quadfasel et al., 1988; Schauer, 1995).

Today, several large glaciers from Spitsbergen drain into Storfjorden with the largest termini situated in the western and northern part. Storfjorden is ice covered for more than seven months per year rendering the fjord inaccessible for ships most of the year. In late summer and early autumn, the fjord is ice free, but the weather is often stormy. Due to the difficult working conditions, it took several consecutive cruises to the area between 2010 and 2016 to obtain sufficient seismic and acoustic data and high-quality cores (between 2005 and 2014) for a detailed mapping and reconstruction of the deglacial history of Storfjorden.

\section{Material and methods}

The study is based on a large database of multibeam bathymetry (MB), acoustic subbottom profiles (Chirp), 2D reflection seismic profiles and marine core data. The mapped part covers the southern, deeper part of Storfjorden (Fig. 1).

\subsection{Cores}

Six gravity cores were taken during four cruises between 2005 and 2014 (Figs. 1, 2; Table 1). Data, AMS- ${ }^{14} \mathrm{C}$ dates and stratigraphy of the cores taken before 2012 plus core HH12-1209GC have been published before in Rasmussen and Thomsen $(2009,2014,2015)$, while data from cores HH12-1212GC and HH14-008GC are new. All core positions were chosen based on acoustic profiles to ensure that the cores would reach into glacial till, or coarse, unsorted sediment of 
111 probable glacimarine origin. Sediments near or on top of the three sediment wedges were targeted 112 (see Section 1). and Thomsen, 2014). The core was split into two halves, X-rayed and described visually. One core

115 half was sliced into 1-cm thick slices, samples were weighed and freeze-dried and weighed again.

116 The percent water content was calculated. Samples taken every four $\mathrm{cm}$ down-core were sieved 117 over sieves with mesh-sizes $63 \mu \mathrm{m}, 100 \mu \mathrm{m}$ and $1 \mathrm{~mm}$. The residues were dried and weighed and 118 the weight percentage of grain sizes calculated. Benthic foraminifera were counted in the $>100 \mu \mathrm{m}$ 119 size-fraction, and concentration as number per gram dry weight sediment calculated. Ice-rafted 120 debris (IRD) was counted from the $>1 \mathrm{~mm}$ size fraction (all mineral grains per sample counted) and 121 the concentration per gram dry weight sediment calculated. Core HH14-008GC was also sampled in 122 a similar way as core HH12-1212GC, but was investigated in lower resolution for lithology and 123 AMS- ${ }^{14} \mathrm{C}$ dates. Note that cores NP05-86GC, JM10-10GC and JM10-12GC were analysed for their 124 content of IRD in a different size fraction of $>0.5 \mathrm{~mm}$ (Rasmussen and Thomsen, 2014). Bivalve shells and/or foraminifera and branched bryozoans were picked for AMS- ${ }^{14} \mathrm{C}$ dating (Fig. 3; Table 2) (see also Rasmussen and Thomsen, 2014). Dating was performed at the 14CHRONO Centre facility at Queen's University, Belfast, Northern Ireland. The new dates and dates from previously published cores were calibrated using the Calib7.04, Marine13 program

129 (Stuiver and Reimer, 1993; Reimer et al., 2013). The global average marine reservoir age correction 130 of 405 years inherent in the calibration program were used (Reimer et al., 2013). Reservoir age 131 changes for the deglaciation period are unknown for the Svalbard margin, and expected to be much 132 larger than the modern $\Delta \mathrm{R}$ of $7 \pm 11^{14} \mathrm{C}$ years (Mangerud et al., 2006; Bondevik et al., 2006). 133 Therefore, no $\Delta \mathrm{R}$ values were applied. The age of the mid-point of 1-sigma errors was chosen. 134 Datings were performed on samples from as close to till sediments and within coarse, unsorted 
135 sediments of probable glacimarine origin to get as accurate ages as possible for the retreat of ice in

136 Storfjorden. All marine ages referred to in this study are calibrated ages before present (=1950) (cal 137 years BP), unless otherwise specified.

\subsection{Acoustics}

The acoustic data were acquired during the 2010 R/V Jan Mayen cruise (JM2010) and the 2012 to 2016 R/V Helmer Hanssen cruises (HH2012 to HH2016). The same shipboard geophysical instruments were used during these cruises. Multibeam-bathymetry mapping (MB) was carried out using a Kongsberg Maritime EM 300 multi-beam echo sounder. Sound-velocity profiles of the water column for calibrating the equipment were recorded from CTD casts when necessary. Subbottom profiles were acquired together with the swath-bathymetry using a hull-mounted EdgeTech 3300-HM (Chirp) instrument. High-resolution reflection seismic data were acquired using a single Sercel GI mini airgun (45 cubic inches) and Fjord Instruments single-channel streamer (6 m active section with 20 hydrophones). velocities of $1470 \mathrm{~m} / \mathrm{s}$ and $1500-1600 \mathrm{~m} / \mathrm{s}$ have been used for depth conversion of the water column and Quaternary-Holocene deposits, respectively.

\section{Results and interpretations}

\subsection{Sediments}


160 sediments barren of foraminifera at their base (Fig. 3). Cores JM10-10GC and JM10-12GC (both 161 taken behind the middle high) also reach into dark-coloured generally foraminifera-barren coarse, 162 unsorted sediments interpreted as glacial diamicton, most likely till (Rasmussen and Thomsen, $1632014,2015)$. Cores HH12-1212GC, JM10-12GC and JM10-10GC contain a diverse fossil macro164 fauna in the upper part or on top of the coarsest sediments consisting of branched and encrusting 165 bryozoans, pteropods, bivalves, gastropods and ophiurians (not quantified). Benthic foraminifera 166 are also present and dominated by Elphidium excavatum and Cassidulina reniforme (Rasmussen 167 and Thomsen, 2015) (Table 2). In core HH12-1212GC, planktic foraminifera are also present (not 168 shown). Core NP05-86GC was taken inside the basin north of the middle high and core HH14008GC was taken on top of the sediment wedge at the mouth of Storfjorden (Figs. 1, 2). The coarse 171 sediments at the lower part of these latter two cores were barren of micro- and macrofossils 172 throughout and interpreted as glacial diamicton (till). All cores thus contain glacial sediments at their lowermost parts that are devoid of microand macrofaunas. The basal sediments are similar in all cores and consist of blackish-dark grey 175 sediments (Munsell colour code; very dark greyish brown 2.5Y-3/2) with high amounts of gravel and large dropstones (Fig. 3). Above the glacial deposits brownish, silty mud (Munsell colour code; greyish brown 2.5Y-5/2) with gravel and dropstones occur, with micro- and macrofaunas of low 178 absolute abundance (Fig. 3). The mid parts of cores generally consist of silty sediments with high 179 absolute abundances of benthic foraminifera and low concentrations of IRD. In the upper parts of 180 all cores, dropstones and IRD increase again (Fig. 3). 

and Thomsen (2014) (Fig. 3). In these records, major events (abrupt start of the Bølling interstadial, Allerød interstadial and Holocene interglacial) could be easily identified and correlated (see e.g., Rasmussen et al., 2007; Rasmussen and Thomsen, 2014, 2015). Due to the reservoir age correction being based on modern values, the ages of the Bølling and Allerød transitions are clearly older than for the same transitions seen in terrestrial records e.g., Greenland ice cores (Rasmussen et al., 2006). In Storfjorden, the start of the Bølling interstadial dates c. 15,600-15,300 years, and the start of the Allerød interstadial c. 14,500 years (Rasmussen and Thomsen, 2014), while these events dates 14,700 and 14,000 years in the NGRIP ice core (based on annual layer counting) (Rasmussen et al., 2006). The age discrepancies are most likely due to increased reservoir ages during the deglaciation (Bondevik et al., 2006). The transition to the Holocene in Storfjorden dates c. 11,700 years, the same as in the NGRIP ice core indicating that reservoir ages became close to modern (see also Bondevik et al., 2006).

Core HH12-1209GC thus dates from the Allerød interstadial $(14,250 \pm 160$ years $)$ above the till at the bottom, while the first marine sediments in core NP05-86GC dates from the beginning of

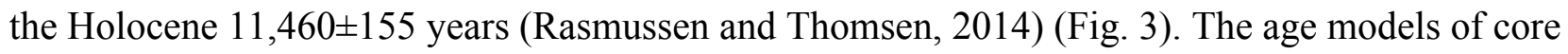
HH12-1212GC, and HH14-008GC were constructed in a similar way to the previously published age models by assuming linear sedimentation rates between dating points (Fig. 3; Table 2). Core HH12-1212GC from the southernmost position at the mouth of Storfjorden has a date of 15,210 75 years $5 \mathrm{~cm}$ above the till. This age is typical for the Bølling interstadial from marine records from the Svalbard margin, which have also used the modern global average reservoir age corrections (see e.g., Ślubowska et al., 2005, Ślubowska-Woldengen et al., 2007; Rasmussen et al., 2007). Core 
HH14-008GC has a date of $7810 \pm 50$ years right above the till (Fig. 3), a date belonging to the 208 Holocene period.

For all records, the probable minimum ages of the micro- and macrofauna barren

210 sediments were calculated by extrapolating the sedimentation rate of the nearest two dates above

211 (Fig. 3). Thus, the top of these deposits have a minimum age of c. 15,300 years in core HH12-

$2121212 \mathrm{GC}$ at the mouth of Storfjorden, c. 14,500 years in core HH12-1209GC further north, c. 12,700

213 in core JM10-12GC, c. 12,600 in core JM10-10GC, and c. 11,600 in NP05-86GC, the three latter

214 cores taken north of the middle high (Fig. 2). For the records of JM10-12GC and JM10-10GC, the

215 dates indicate a Younger Dryas age of the deglaciation of the sites. However, the sediments were

216 most probably of younger age, because of unknown reservoir age correction (see discussion in

217 Rasmussen and Thomsen, 2014, 2015). Therefore, the age of the top of the till at these two sites are 218 assumed to be close to the Younger Dryas-Holocene transition between c. 12,000 and 11,700 years 219 (Fig. 3).

From the age models it has also become apparent that core HH12-1209GC contains a

221 hiatus/or that sedimentation rates were very low in the mid to late Holocene at that location, and the 222 same appears to be true for the early-mid Holocene section of core JM10-10GC (Fig. 3)

223 (Rasmussen and Thomsen, 2014, 2015). The young age of sediments (Holocene) right above the till 224 in core HH14-008GC taken near core HH12-1212GC on top of the outer GZW also indicates 225 presence of a hiatus (Fig. 3). Core HH12-1212GC shows very low sedimentation rates between the 226 ages of 13,815 years (Allerød interstadial) and 8870 years (early to mid-Holocene) (Fig. 3). 
Three seismic horizons were mapped throughout the study area, bounding two seismic units.

231 Based on their seismic character and the results from the sediment cores described above, the seismic horizons are named 'Top Pre-Quaternary' (TPQ), 'Top Glacial' (TG) and 'Seabed', and the seismic units informally termed 'glacial deposits'(GD) and 'deglacial to Holocene deposits' (DHD). The character of the bounding horizons and the two seismic units are illustrated by the seismic line crossing N-S over the central study area (Fig. 4a,b). The morphology of horizon TPQ and the total thickness of the overlying seismic units are illustrated by time-structure and timeisochore maps, respectively (Fig. 5a,b) and the thickness of units GD and DHD are shown by the time-isochore maps (Fig. 5c,d). The different units and maps are described in more details in the 239 following.

\subsubsection{The TPQ surface and pre-Quaternary section}

The TPQ horizon is the deepest, relatively continuous reflection seen on the 2D seismic data in the present study. The seismic reflection pattern of the underlying section shows stratified and faulted strata (Figs. 4, 6). The age of these strata is unknown, however, they are likely of Mesozoic or older age (Faleide et al., 1984). In the following, this pre-Quaternary section will be referred to as 'the basement'. The overall morphology of the TPQ horizon mimics that of the present seabed with ridges and lows (Fig. 5a). The depth to this horizon within the study area varies from more than 300 ms two-way time (TWT) ( 220 m) below the sea-surface (bss) in the south to less than 50 ms TWT ( 35-40 m) bss towards northeast near Edgeøya, where it crops out at the seabed (Fig. 5a,b). In the southwest, at the eastern flank of the Mid-ridge, the TPQ lies around $120 \mathrm{~ms}$ TWT 251 ( $\sim 90-100 \mathrm{~m})$ bss, and further to the east, it constitutes the core of the Mid-ridge (Fig. 6d). In the central part of the study area, the TPQ forms an E-W striking structure that rises to almost $180 \mathrm{~ms}$ TWT ( $\sim 130 \mathrm{~m})$ bss, constituting the middle high. North of the ridge, the TPQ surface forms a basin 
that reaches a depth of more than 250 ms TWT ( 195 m) bss, while the horizon south of the ridge dips gently southwards reaching a depth of c. $275 \mathrm{~ms}$ TWT $(\sim 200 \mathrm{~m})$ bss before plunging into Storfjorden Trough. Here a relatively flat E-W striking ridge constitutes the outer high (see also

Figs. 4, 6e). To the north, TPQ forms a SW-NE striking narrow and discontinuous ridge that rises to about $160 \mathrm{~ms}$ TWT ( $115 \mathrm{~m}$ ) bss (Fig. 5a). To the south of this narrow ridge lies a broad, slightly elevated area striking SW-NE that constitutes the inner high (see also Figs. 4a, 6a). To the north of the narrow ridge lies a basin, that reaches a depth of more than $250 \mathrm{~ms}$ TWT ( $\sim 195 \mathrm{~m})$ bss. Further north, the TPQ rises higher than $75 \mathrm{~ms}$ TWT ( $\sim 55 \mathrm{~m})$ bss.

\subsubsection{The Quaternary-Holocene sediment thickness and the GD unit}

The distribution of the total sediment thickness (Fig. 5b) reveals three depo-centres up to 50 ms TWT thick ( 35-40 m), all striking in a southwest-northeasterly direction. When compared to the thickness of unit GD (Fig. 5c) it is seen that these depo-centres are mainly built-up by sediments belonging to this unit. Thickness distribution combined with their overall wedge-shaped geometry and transparent to weakly progradational internal reflection patterns (Figs. 4, 6), these depo-centres are interpreted to be GZWs deposited by a line-sourced delivery of sediments (e.g. Batchelor and Dowdeswell, 2015). The three GZWs are named after their relative position within the fjord and thus called inner, middle and outer GZW. The middle GZW stands out as the shallowest area compared to the surrounding present-day seabed, and as a result the seaward slopes of the inner and outer GZWs appear less prominent (Figs. 4, 7a). All three GZWs span the study area, are 10-12 km wide in N-S direction, strike SW-NE and are c. $25 \mathrm{~km}$ long, and have relatively steep seaward slopes (Figs. 6, 7a). We note that whilst the thickest part of the inner GZW lies close to the midridge towards the west (Fig. 5c) and its thickness is more evenly distributed across the width of the wedge, the thickest parts of the middle and outer GZW are their southeastern sides (Fig. 5c). 
The thickness of unit GD outside the GZWs is generally less than $10 \mathrm{~ms}$ TWT $(\sim 7.5-8 \mathrm{~m})$, being thinnest $(0-5 \mathrm{~ms}$ TWT; $\sim<\mathrm{m})$ between the middle and outer GZW and thickest (c. $12 \mathrm{~ms}$ TWT; $\sim 10 \mathrm{~m}$ ) in the basin between the middle and inner GZW (Fig. 5c).

\subsubsection{The DHD unit}

The DHD unit generally drapes and fills basinal structures of the TPQ horizon (Figs. 4 and

$5 \mathrm{~d})$. The unit is absent or very thin $(0-4 \mathrm{~ms}$ TWT; $\sim 0-1.5 \mathrm{~m})$ on the southeastern flank of the Midridge and on top of the outer and middle GZWs. The western part of the inner GZW is covered by up to $4 \mathrm{~ms}$ TWT $(\sim 1.5 \mathrm{~m})$ thick layer of DHD deposits, which thickens to almost $10 \mathrm{~ms}$ TWT $(\sim 7.5$ m) on the northeastern part of the inner GZW. The thickest parts of unit DHD (15-20 ms TWT; 11-15 m) are found in the two basins of the TPQ horizon, i.e. between the middle and inner GZW and north of the inner GZW (Fig. 5a,d). Less prominent DHD depositions (6-8 ms TWT; 4.5-6 m) are seen towards east between the middle and outer GZW, and south of the outer GZW.

\subsubsection{Grounding-zone wedges}

Whilst the three GZWs are found in a similar setting on the southern, down-flow side of higher-lying basement areas, their morphology and seismic style differ (Figs. 4, 5).

The inner GZW is characterized by a slightly southeastwards dipping surface and a gentle 296 ice-distal slope (Fig. 6a,b), and has an arcuate shape facing southeast (Fig. 5c). The internal 297 reflection pattern is mostly transparent to chaotic, yet a clear prograding sub-unit is seen in the 298 lower part immediately down-flow of the inner high (Fig. 6a,b). This sub-unit is found only in the central section of the inner GZW indicating a restricted, point-sourced sediment delivery as compared to the larger, line-sourced sediment delivery of the inner GZW. It is therefore interpreted 
front of an ice margin cliff by a sub-marine meltwater stream. Another sub-unit was observed below the ice-distal slope of the inner GZW (Fig. 6a). It has a ridge-like form and a chaotic internal reflection pattern, and could be followed outside the GZW as an E-W striking ridge. (e.g., Dowdeswell et al. 2016). As part of the ridge is covered by the inner GZW, its formation evidently pre-dates the deposition of the inner GZW. Similar ridges are also observed to the south (see

\section{Section 4.3.5.).}

The middle GZW is characterized by a ramp-like morphology with a steep south-facing slope (Fig. 5c).Its overall shape in plan view is curved, but with some bulging parts indicating

311 progradational pattern, but are clearly blurred by the diffraction noise from a heavily chopped 312 seabed reflector (Fig. 6c,d). The latter is the result of iceberg keels having ploughed the seafloor on 313 top of the GZW after its formation (see also Fig. 8c).

314 The outer GZW shows a flat morphology with a smooth and rounded southern slope (Fig. $3156 \mathrm{6}, \mathrm{f}$ ), and a curved overall outline in plan view similar to the inner and middle GZWs (Fig. 5c). The 316 internal reflection pattern is transparent to chaotic, though disturbed by diffraction noise from the 317 iceberg ploughed seabed (Figs. 6e,f, 7d).

\subsubsection{Recessional ridges}

Small ridges similar to the ridge buried under the inner GZW (Fig. 6a,b) are also observed in

321 the areas between the three GZWs. They all overlie the PQ basement and have a chaotic to 322 transparent internal reflection pattern suggesting till deposits (Fig. 7). The ridges are here 323 interpreted to be recessional ridges formed during temporary halts in the ice retreat in front of an ice 324 cliff (e.g., Dowdeswell et al., 2016 and references herein). The majority of the ridges are symmetrical in cross-section and are on average not more than $5 \mathrm{~ms}$ TWT ( $4 \mathrm{~m})$ high (Fig. 7). 
However, two ridges are up to 10-12 ms TWT $(8-9 \mathrm{~m})$ high and are asymmetric in cross-section with a steeper flank facing north (Fig. 7). This could indicate some push to the formation of these two larger ridges, e.g., by a slight advance of the ice front. It should, however, be noted that these two ridges are found in an area prone to earthquakes (Pirli et al., 2013; Junek et al., 2014), and thus some elements of structural displacement and/or sediment mobilisation in connection with earthquake activity may have altered the ridges. The recessional ridges are primarily observed in the western Storfjorden and are all covered by unit DHD sediments. The cover over the ridges found south of the middle GZW is relatively thin 334 (Fig. 5b) and are seen in the seabed morphology (Fig. 8c; Section 4.2.4.). In contrast, the ridges 335 found between the inner and middle GZWs are completely covered by a much thicker layer of unit 336 DHD sediments (Fig. 5b), and are therefore not visible on the present seabed (Fig. 8c; Section 337 4.2.4.). However, some of the ridges in this area can be seen on the thickness (time-isochore) map of the glacial deposits as small elongations of slightly thicker deposits (Fig. 5c).

\subsubsection{Multibeam bathymetry mapping}

The overall seabed morphology seen on the multibeam bathymetry (MB) map (Fig. 8a) confirms the ridge and basin structures previously reported from Storfjorden (Plassen et al., 2008).

343 Furthest to the north the seabed displays a hummocky terrain, which changes southwards into an 344 area characterized by a succession of depressions and ridges (Fig. 8b). A series of parallel, 345 southeastwards curving lineations are located on the southern flank of the ridge structure. The 346 seismic and chirp data reveal that both the hummocky terrain and the depression-ridge morphology 347 are underlain by the basement that, apart from the highest peaks, are lightly draped and partly 348 infilled by the deglacial-Holocene sediments of acoustic unit DHD. This suite of seabed landforms 349 are interpreted as subglacial, and include an ice-moulded basement surface to the north that 
continues into an eroded and glacitectonically deformed high-lying basement area, forming depressions and ridges with stoss- and lee-sides. The lineations observed on the lee-sides of the ridges likely formed later as grounded ice continued to flow southwards over the ridges (cf. Bennett et al., 2016); and their curved outline is most likely caused by a slight deflection of the ice flow due to the drag imposed by the basement high obstructions. South of the depression-ridge basement area, the seabed shows an iceberg-scoured terrain that terminates with a south-facing slope (Fig. $8 \mathrm{~b})$. The seismic and Chirp data show that this seabed morphology is controlled by the inner GZW (see Section 4.3.). The seabed south of the inner GZW is rather featureless due to smoothing by the thicker unit DHD cover in that area (Fig. 5b).

Fig. 8c illustrates the seabed morphology of the central study area and shows the intensely 360 iceberg scoured surface of the middle GZW and its curved ice-distal slope. South of the wedge, a 361 series of prominent seabed ridges extend eastwards from the Storfjorden Mid-ridge. Further east, more subtle E-W striking ridges are also visible (Fig. 8c). These features are the seabed expression of the recessional ridges (Fig. 7; Section 4.3.5.). Whilst the less prominent, but longest ridges are spaced fairly regularly with a c. $850 \mathrm{~m}$ distance between ridges, the two more prominent

365 discontinuous ridges extending out from the Storfjorden Mid-ridge lie c. $500 \mathrm{~m}$ apart. These are the larger asymmetric ridges discussed above (Fig. 7; Section 4.3.5.).

The seabed morphology in the outer study area is illustrated in Fig. 8d and shows the relatively flat top of the outer GZW with iceberg scours. The most striking features in this area are several large, N-S striking linear scours that disappear underneath the front of the outer GZW, and some of which extend outside our data coverage (Fig. 7d). The displayed parts of the scours are up to $0.5 \mathrm{~km}$ wide and more than $5.5 \mathrm{~km}$ long. However, their full length and shape cannot be determined due to the partial burial and data limitation. The shape and size of the displayed part of the scours resemble parts of mega-scale glacial lineations (MSGLs) described from other fjords and 
shelves around Svalbard and elsewhere in the Arctic (e.g. Ottesen et al., 2005; Dowdeswell et al., 2008, 2010). Alternatively, these large linear features may result from scouring by large, multikeeled icebergs calved when the ice margin was at the outer high and prior to the formation of the outer GZW. Considering the number of the scours and their uniform and parallel directions, together with their large size and partial burial by the outer GZW, we suggest they are MSGLs. Lifting-off of the ice that formed the MSGLs due to deepening water or truncation by the ice in Storfjorden Trough, may explain the termination of the two central MSGLs at the mouth of

381 Storfjorden. As seen in Fig. 8d, the MSGLs are cross-cut by several iceberg ploughmarks that 382 evidently must post-date the formation of the MSGLs.

\section{Discussion}

During the LGM at c. 24,000 years, the Svalbard-Barents Sea Ice Sheet reached to the shelf edge (e.g., Elverhøi et al., 1995; Landvik et al., 1998; Jessen et al., 2010). The ice began retreating from the western shelf edge before 20,000 years BP (e.g., Jessen et al., 2010; Hormes et al., 2013) and by the start of the Holocene, the ice had retreated into the inner parts of fjords

390 (Svendsen et al., 1992, 1996; Elverhøi et al., 1995; Hogan et al., 2017).

\subsection{Deglaciation history and ice retreat patterns in Storfjorden}

\subsubsection{Start of Bølling interstadial c. 15,300 years}

For core HH12-1212GC from the mouth of Storfjorden in front of the outer GZW, the 396 minimum age of 15,300 years for the top of the till indicates the ice had retreated from the core 397 location in the early Bølling interstadial (Figs. 3, 9a, 10). The overriding of the MSGLs at the 
mouth of Storfjorden by the outer GZW (Fig. 8d) confirms to that these subglacial lineations were formed prior to deposition of the wedge, i.e. before the start of the Bølling interstadial. For core HH12-1212GC, the coarse sediments and high concentration of IRD and dropstones together with presence of numerous specimens of the benthic foraminiferal species Elphidium excavatum (Table 2) indicate an ice-proximal glacimarine environment and that the coring site was near the grounding-zone of the outer GZW at the start of the Bølling interstadial (Fig. 3; Table 2). The diamictic sediments are interpreted as a till probably deposited from below a floating ice shelf (cf. Kilfeather et al., 2011). This is supported by the presence of benthic and planktic foraminifera and ostracods together with a diverse (but of few individuals) assemblage of invertebrates such as both branched and encrusting bryozoans, pteropods, ophiurians, bivalves and gastropods. The presence of planktic faunas (foraminifera and pteropods) indicates a fairly strong intrusion of marine water to the site following the retreat of the grounded ice. The presence of benthic micro- and macrofaunas (including suspension feeders) and planktic foraminifera and pteropods has recently been recorded below floating ice shelves in Antarctica (Riddle et al., 2007; Post et al., 2007; Sugiyama et al., 2014; Rose et al., 2015). The bryozoans indicate water movement and sufficient supply of food to the community. The low concentration of specimens and extremely good preservation also indicate low productivity typical of sub-ice environments (Riddle et al., 2007). The outer GZW lies close to the mouth of Storfjorden in an area where water depth begin to shallow in the fjord. It is thus likely that when the ice retreated from the deeper Storfjorden Trough (200-300 m present-day water depth) and into Storfjorden, the shallower (100-200 m) seabed and shallow fjord flanks $(<100 \mathrm{~m})$ acted to stabilise the retreating ice (cf. Jamison et al., 2014), giving rise to deposition of the outer GZW. The flat morphology of the outer GZW likely reflects a relatively restricted vertical accommodation space under the floating ice margin. Core JM09-020GC from south of Storfjorden in the southern part of Storfjorden Trough (Fig. 2) has a basal date of c. 
14,000 years for ice retreat (Lacka et al., 2015), more than a thousand years later than at the site of core HH12-1212GC. This indicates that the ice located on Spitsbergenbanken and/or further to the east in Storfjorden Trough probably reached into the southeastern part of Storfjorden Trough, while it had retreated from the northern part into the mouth of Storfjorden at the start of the Bølling interstadial (Fig. 2). The inner part of Kveithola Trough, which incises the western part of Spitsbergenbanken just south of the area shown in Fig. 2, deglaciated before 14,700 years and probably even earlier for the outer part (Rüther et al., 2012; Bjarnadottir et al., 2013). In inner Kongsfjorden Trough at $79^{\circ} \mathrm{N}$, marine sediments above till date between 16,300 and 14,650 years also indicating a Bølling age (Landvik et al., 2005) (calibrated by Calib7.04, Marine 13, -405 years reservoir correction; see Methods Section 3). Marine dates from outer parts of the northern Svalbard shelf in Hinlopen Trough, $80^{\circ} \mathrm{N}$ gave an age of c. 16,550 for ice retreat (Ślubowska et al., 2005) supported by dates from north of Nordaustlandet further east (Chauhan et al., 2016; Hogan et al., 2017) and the western shelf of Svalbard (Bellsund Hola, $77^{\circ}$ N; Ślubowska-Woldengen et al., 2007). Dates from the southwestern shelf (Storfjorden Trough; $76^{\circ} \mathrm{N}$; Rasmussen et al., 2007) indicate early retreat of the ice margin from about 20,000 years. It appears the outer parts of cross-shelf troughs deglaciated well before the Bølling interstadial, while the inner parts deglaciated at the start of the Bølling interstadial in accordance with modelling results of ice retreat from the western Svalbard margin (Patton et al., 2016) (see also review and references in Hormes et al., 2013 and Hogan et al., 2017). In Storfjorden, this large step of retreat of the grounding-zone into the fjord at the start of 443 Atlantic Water as seen in other records from Storfjorden Trough (e.g., Rasmussen et al., 2007), 444 from the Svalbard shelf (Ślubowska et al., 2005; Ślubowska-Woldengen et al., 2007) and the 445 Barents Sea (e.g., Lubinski et al., 2001; Aagaard-Sørensen et al., 2010; Kristensen et al., 2013). The 
retreat phase is also close in time to the first abrupt atmospheric deglacial warming as recorded in

447 Greenland ice cores (Rasmussen et al., 2006). The high concentration of coarse IRD $>1 \mathrm{~mm}$ in core HH12-1212GC (Fig. 3) indicates strong melting or increased calving of icebergs over the core site at the time, probably as a result of the oceanic and atmospheric warming.

5.1.2. Start of Allerød interstadial c. 14,500 years and Younger Dryas cold period c. 13,000-11,700 years

Core site HH12-1209GC in front of the middle GZW deglaciated at the start of the Allerød interstadial (Rasmussen and Thomsen, 2014) (Figs. 1-3, 9b, 10). This phase of ice retreat in Storfjorden also correlates with strong (sub)surface inflow of Atlantic water to Storfjorden, the Svalbard shelf and Barents Sea recorded by increases in planktic and benthic foraminifera and warmer surface water conditions (e.g., Polyak and Solhein, 1994; Polyak and Mikhailov, 1996; Lubinski et a., 2001; Ślubowska et al., 2005; Ślubowska-Woldengen et al., 2007; Rasmussen et al., 2007; Aagaard-Sørensen et al., 2010; Rasmussen and Thomsen, 2015) (Fig. 3). the Younger Dryas-Holocene transition around 12,000-11,700 years (Figs. 9d, 10). This may suggest that the grounding-zone could have stayed on the middle high for almost 3000 years (c. 14,500-12,000/11,700 years) depositing the middle GZW. During this long period, the middle 464 GZW would have prograded seawards and started in-filling the increasing accommodation space 465 that arose as the ice shelf became thinner away from the ice front, explaining the ram-like 466 morphology of the middle GZW. However, given that the time interval includes the cold Younger 467 Dryas stadial (dating 12,900-11,700 in ice cores (Rasmussen et al., 2006)), it is also possible that 468 the ice was grounded on the middle high for the duration of the Younger Dryas (c. 1200 years) 469 depositing the middle GZW. If the grounding-zone was at the middle GZW during the Younger 
Dryas, it could explain the high deposition rates of coarse material in core HH12-1209GC during

471 this time interval compared to the site of HH12-1212GC further away from the grounding-zone

472 (Fig. 3). It is, however also possible the ice even advanced beyond the middle high during the

473 Younger Dryas, and destroyed any GZW it may have been deposited during the Allerød interstadial.

474 An alternative scenario could be that the ice retreated across the middle high and farther into the

475 fjord during the Allerød interstadial, perhaps as far as to the inner high (Fig. 1). Here it could have

476 formed an ice margin cliff and deposited the ice-proximal fan found buried under the inner GZW

477 (Fig. 6a,b). Subsequently, during the cold Younger Dryas stadial the ice re-advanced to the middle

478 high where it grounded and deposited the middle GZW (Figs. 4, 9c, 10). This scenario

479 accommodates both the observations at the coring sites of lithology and dates, the presence of the

480 ice-proximal fan underneath the inner GZW and deposition of the middle GZW (Figs. 4, 6c).

481 Survival of the ice-proximal fan during the re-advance would though, imply that the ice was cold-

482 based and non-erosive during the early ice advance at the onset of the Younger Dryas cooling, at 483 least around the inner high area. However, the fan may also have been deposited during the same 484 period as the inner GZW as suggested for similar examples of ice margin deposits observed in 485 Kveithola (Bjarnadöttir et al., 2013).

Although the grounding of the ice at the inner high is speculative, we favour the scenario 487 where the ice retreated across the middle high and farther into Storfjorden (Figs. 9b,c, 10) as this 488 seems to best fit the core results. The dates from JM10-12GC taken in the basin behind the middle high and JM10-10GC

492 from same basin (Fig. 2) show that ice persisted here until close to the start of the Holocene (see 493 Section 5.1.2.). The sediments with numerous coarse mineral grains at the bottom of cores JM10- 
12GC and JM10-10GC contain similar benthic and planktic macro- and microfaunas dominated by

E. excavatum as found in HH12-1212GC indicating an ice-proximal environment (Rasmussen and Thomsen, 2014). The ice probably had retreated sometime during the Younger Dryas-Holocene transition and sediments were deposited under an ice shelf at these sites. As in HH12-1212GC, the faunas were extremely well-preserved indicating low productivity of the environment (and probably no reworking) (see Section 5.1.1.). In core NP05-86GC, the first marine sediment dates to 11,600 years shortly after the start of the Holocene interglacial (Fig. 3). The lowermost coarse, unsorted sediments are devoid of macro- and microfaunas indicating that the sediments were deposited close to the grounding-zone, and that the site of NP05-86GC only became free of ice at the very start of the Holocene (Rasmussen and Thomsen, 2014) and slightly later than the two other sites JM10-

504 12GC and JM10-10GC, which were free of the ice at the Younger Dryas-Holocene transition (see Section 5.1.2.). The location of the inner GZW at the northern end of the basin also indicates that this part deglaciated later than the sites of JM10-10GC and JM10-12GC to the northeast and south, respectively (Figs. 1, 2, 4, 10). This suggests that the grounding-zone retreated faster and farther north on the eastern part of Storfjorden than on the western and northern parts, as also indicated by 509 the seismic and acoustic data (see below). The time correlates with intrusion of subsurface Atlantic 510 water to Storfjorden probably inflowing at the eastern margin toward Edgeøya as today (e.g., 511 Rasmussen and Thomsen, 2015) (Fig. 2). Terrestrial and marine dates from Edgeøya also show that 512 ice had retreated from the coast at the Younger Dryas-Holocene transition at 12,000-11,200 years 513 (Landvik et al., 1995 and references therein; Hansen and Knudsen, 1995; Bondevik et al., 1995). The last retreat phase in Storfjorden at the Younger Dryas-Holocene transition and the 515 beginning of the Holocene occurred at a time of abrupt atmospheric warming known from 516 Greenland ice cores (e.g., Rasmussen et al., 2006). It is also a phase marked by a massive intrusion 
of (sub)surface Atlantic Water to the western Svalbard margin and the Barents Sea (e.g., Skirbekk et al., 2010; Risebrobakken et al., 2010; Berben et al., 2014; Rasmussen et al., 2014).

Although the cores indicate the presence of an ice shelf in the eastern Storfjorden, the western part may have lacked an ice shelf as suggested by the occurrence of recessional ridges between the middle and inner GZW, which demonstrate that the retreat of grounded ice over this part of Storfjorden was punctuated by short still stands. The partial burial of the northernmost recessional ridge by the inner GZW and the burial of ridges by seismic unit DHD (Figs. 6, 7), indicate that these ridges were formed as the ice retreated from the middle high onto the inner high, where it eventually stayed grounded for a period long enough to deposit the inner GZW.

The fact that the recessional ridges increase in size towards west and connect to the eastern flank of the Mid-ridge suggests that the Mid-ridge may have enforced a lateral drag on the retreating ice by acting as a pinning point for the ice sheet. Thus, while the retreating ice in the western Storfjorden this way experienced short, temporary halts due to the lateral drag from the Mid-ridge, the grounded ice in eastern Storfjorden was more prone to flotation due to inflow of 531 subsurface Atlantic water to the east (Fig. 10), and eventually an ice shelf developed in the 532 easternmost Storfjorden as indicated by the core studies. The recessional ridges found between the outer and middle GZWs show that the a lateral drag forced by the Mid-ridge also acted during the previous (post-LGM) ice retreat events in Storfjorden, which may explain the observed overall SWNE trend of all three GZWs.

The rather short duration of the Younger Dryas-Holocene transition period (c. 300 years) indicates that the retreat of the ice from the middle high to the inner high must have occurred relatively fast. A fast retreat of the ice over the ice-proximal fan could explain how the fan could survive the over-running of the ice that eventually grounded on the inner high north of the fan, and subsequently deposited the inner GZW on top of the fan. 
After deposition of the inner GZW, ice retreat continued further into Storfjorden, and at the very onset of the earliest Holocene the ice might have reached the basement area characterized by series of depressions and ridges (Fig. 8b) in inner Storfjorden (Fig. 9e). This scenario is supported by the results of core NP05-86GC, which indicated that the core site was ice free, but located in an ice proximal position around 11,600 years (see Section 5.1.4.). The depression and ridge area, however, likely existed prior to the glaciation of Storfjorden as a high-lying, structurally deformed basement area characterized by ridges and basins. As the glaciation of Storfjorden progressed from the north, the area was overridden and likely altered by the ice several times.

\subsubsection{Earliest Holocene c. 11,700-10,000 years and Holocene 10,000-0 years}

The earliest Holocene in all cores is characterised by high concentration of IRD deposited between c. 11,700 and 10,000 years (Fig. 3) indicating further retreat and break-up of the ice stream. After 10,000 years, IRD decreases in several of the records. This general decrease in ice rafting is also recorded north and west of Svalbard also dating around 10,000 years indicating that the ice now was situated inland (Ślubowska et al., 2005, Ślubowska-Woldengen et al., 2007; Forwick and Vorren, 2009). Ice rafting thereafter became very low over the Svalbard-Barents Sea margin. This pattern is also evident in Storfjorden as coarse IRD becomes almost absent after 10,000 years BP in all records with low or no deposition of IRD in the mid-Holocene and increased ice-rafting in the late Holocene (see also Rasmussen and Thomsen, 2015) (Fig. 3). The patterns also

560 resemble patterns seen elsewhere on the shelf west and north of Svalbard (Ślubowska et al., 2005,

561 Ślubowska-Woldengen et al., 2007, Skirbekk et al., 2010; Groot et al., 2014), in Svalbard fjords 562 (Forwick and Vorren, 2009) and to some extent also east of Svalbard (Kristensen et al., 2013). The 563 content of IRD also increases during the late Holocene in many published records from the 564 Svalbard margin. This is taken as an indication that the glaciers again reached into marine waters; 
565 also termed the neoglaciation (e.g., Hald et al., 2004; Ślubowska et al., 2005, Ślubowska-

566 Woldengen et al., 2007; Forwick and Vorren, 2009; Skirbekk et al., 2010; Jessen et al., 2010).

\subsection{Ice retreat and forcing}

The different phases of deglaciation in Storfjorden (at the start of the Bølling interstadial,

Allerød interstadial and Holocene interglacial) apparently correlate closely in time to abrupt warming phases and intrusions of (sub)surface Atlantic water. From paleorecords, it has previously been suggested that sea surface warming probably caused retreat and break-up of Northern Hemisphere ice shelves (e.g., Rasmussen et al., 1996; Schaffer et al., 2004; Marcott et al., 2011). Modern data from both the Greenland margin (e.g., Howat et al., 2005; Holland et al., 2008) and Antarctica (e.g., Jeong et al., 2016 and references therein) have shown that incursions of subsurface warm water underneath ice shelves and outlet glaciers cause accelerated melting and calving. The evidence from Storfjorden of ice retreat in step with atmospheric and ocean warming indicates a strong forcing from the ocean and atmosphere on the timing of the retreat. However, our reconstruction of the Storfjorden deglaciation also demonstrates that the ice-retreat pattern was 581 linked to the bed topography of the fjord as all three GZWs are found down-flow of higher lying basement areas, where the ice likely have been grounded for a longer period. This is in accordance with other studies and modelling of e.g. Stokes et al. (2007), Jamieson et al. (2014) and Favier et al.

584 (2016), who suggested that the temporal and spatial variability of an ice flow is intimately linked to 585 the distribution of sticky points at its base.

An ice flow out of Storfjorden has often been suggested or inferred, but here we have demonstrated the existence of this ice flow by reconstruction of the deglaciation of Storfjorden. An earlier reconstruction of ice extent over Svalbard suggested the presence of an ice dome over 
northeastern Svalbard during the LGM, which drained only towards north, east and west

590 (Dowdeswell et al., 2010; Hogan et al., 2010b). Based on our results we now suggest that this ice

591 dome also drained southwards through Storfjorden. We envision that the dome, in order to have had

592 ice enough to also accommodate a southward ice flow, must have been larger than previously

593 assumed and that it extended further south covering the narrow strait between the islands of

594 Spitsbergen and Barentsøya (Fig. 1).

\section{Conclusions}

By integrating seismic, Chirp and multibeam bathymetry data with information from cores on sediment, IRD, fossil faunas and dates, the pattern and timing of the ice sheet retreat after the Last Glacial Maximum in Storfjorden, southern Svalbard have been reconstructed in detail and conceptually illustrated in Figs. 9 and 10:

a) During Bølling interstadial, c. 15,300 years, the ice front was located in the outer Storfjorden and formed the outer grounding-zone wedge (GZW). A large floating shelf reached at least to the mouth of the fjord (Figs. 9a, 10)

b) During the Allerød interstadial, c. 14,500 years, ice retreated into Storfjorden, maybe as far as the position of the present inner GZW. Here, it could have formed an ice cliff and deposited an ice-proximal fan (Figs. 9b, 10)

c) We suggest that a re-advance occurred during the Younger Dryas stadial. At c. 13,000 years, the ice front stood c. $50 \mathrm{~km}$ inside the fjord and formed the middle GZW. Apparently, the ice shelf was not very extensive at that time (Figs. 9c, 10)

d) During the transition from Younger Dryas to Holocene, c. 12,000-11,700 years, a large floating ice shelf had developed and the ice was grounded around the inner GZW (Figs. 9d, 10). The ice retreat was slowed down toward west, while open water was present to the east 
e) The ice continued the retreat in the early Holocene, and at c. 11,600 years the ice was likely grounded in the high-lying, rough basement area north of the inner GZW (Figs. 9e, 10)

f) At 10,000 years, large armadas of icebergs marked the final retreat of the marine based ice in Storfjorden and ice rafting ceased or became very low thereafter. During the last c. 3000 years in the late Holocene ice rafting increased, a sign that glaciers again reached Storfjorden (Fig.

The timing of the various stages of ice retreat recorded in Storfjorden correlates closely with abrupt atmospheric warmings of the start of the Bølling and Allerød interstadials, at the Holocene interglacial and intrusions of Atlantic water to the shelf and fjords. Basement highs acted as pinning points causing longer still-stand periods during the ice retreat and giving rise to deposition of the three GZWs. The N-S striking Mid-ridge that flanks the western side of Storfjorden (Fig. 1) recessional ridges in western Storfjorden and a slight deflection of the grounding-zones (Fig. 10). This angling of the ice retreat probably further accelerated by incursions of warm Atlantic water along the east coast. topography on the timing and pattern of an ice retreating from an Arctic fjord setting. Further, we

633 have confirmed the existence of a so far only assumed ice flow out of Storfjorden, and suggest that 634 this ice flow may have emanated from a larger version of the previously proposed LGM ice dome 635 over northern Svalbard.

637 Acknowledgement. Our sincere thanks to the captains and crews of RV Jan Mayen/Helmer 638 Hanssen for their patience and hard work during the numerous more or less successful cruises to 
639 stormy and sea-ice covered Storfjorden, and to the many different staffs on-board for core handling

640 and data logging. Special thanks to engineers S. Iversen and B.R. Olsen for data handling and

641 processing and E. Thomsen for making the map in Fig. 2. We also thank three anonymous

642 reviewers for the very helpful reviews and suggestions for improvement of the manuscript. C.

643 Lockwood is thanked for handling of core HH14-008GC. This yearlong study was supported by the

644 Paleo-CIRCUS project funded by UiT, the Arctic University of Norway, and the Mohn Foundation 645 and since 2013, also by the Research Council of Norway through its Centres of Excellence funding 646 scheme, project number 223259. T. Nielsen received funding from the People Programme (Marie 647 Curie Actions) of the European Union's Seventh Framework Programme P7/2007-2013/ under REA 648 grant agreement no. 317217. 


\section{References}

Aagaard-Sørensen, S., Husum, K., Hald, M., Knies, J., 2010. Paleoceanographic development in the SW Barents Sea during the late Weichselian-Early Holocene transition. Quat. Sci. Rev. 29, 3442-3456.

Batchelor C.L and Dowdeswell J.A., 2015. Ice-sheet grounding-zone wedges (GZWs) on highlatitude continental margins. Mar. Geol. 363, 65-92

Berben, S.M.P., Husum, K., Cabedo-Sanz, P., and Belt, S.T., 2014. Holocene sub-centennial evolution of Atlantic water inflow and sea ice distribution in the western Barents Sea, Clim. Past, 10, 181-198.

Bjarnadóttir, L.R., Rüther, D.C., Winsborrow, M.C.M., Andreassen, K., 2013. Grounding-line dynamics during the last deglaciation of Kveithola, W Barents Sea, as revealed by seabed geomorphology and shallow seismic stratigraphy. Boreas 42, 84-107.

Bondevik, S., Mangerud, J., Ronnert, L., Salvigsen, O., 1995. Postglacial sea-level history of Edgeøya and Barentsøya, eastern Svalbard. Polar Res. 14, 153-180.

Bondevik, S., Mangerud, J., Birks, H. H., Gulliksen, S., Reimer, P., 2006. Changes in North Atlantic radiocarbon reservoir ages during the Allerød and Younger Dryas. Science 312, $1514-1517$.

Chauhan, T., Rasmussen, T.L., Noormets, R., 2016. Paleoceanography of the Barents Sea continental margin, north of Nordaustlandet, Svalbard during the last 74 ka. Boreas 45, 7699.

Dowdeswell, J.A., Canals, M., Jacobsson, M., Tood, B.J., Dowdeswell, E.K., Hogan, K.A., 2016. The varity and distribution of submarine glacial landforms and implications for ice-sheet reconstruction. In: Dowdeswell, J.A., Canals, M., Jakobsson, M., Todd, B.J., Dowdeswell, E.K., Hogan, K.A. (eds), Atlas of Submarine Glacial Landforms:Modern, Quaternary and Ancient. Geol. Soc. London, Mem. 46, 211-212.

Dowdeswell, J.A., Ottesen, D., Evans, J., Ó Cofaigh, C., Anderson, J.B., 2008. Submarine glacial landforms and rates of ice-stream collapse. Geology 36, 819-822.

Dowdeswell, J.A., Hogan, K.A., Evans, J., Noormets, R., Ó Cofaigh, C., Ottesen, D., 2010. Past ice-sheet flow east of Svalbard inferred from streamlined subglacial landforms. Geology $38,163-166$.

Dowdeswell, J.A., Fugelli, E.M.G., 2012. The seismic architecture and geometry of grounding-zone wedges formed at the marine margins of past ice sheets. GSA Bull. 124, 1750-1761. 
Dowdeswell, J.A., Siegert, M.J., 1999. Ice-sheet numerical modelling and marine geophysical measurements of glacier-derived sedimentation on the Eurasian Arctic continental margins. GSA Bull. 111, 1080-1097.

Elverhøi, A., Svendsen, J.I., Solheim, A., Andersen, E.S., Milliman, J., Mangerud, J., Hooke, R. LeB., 1995. Late Quaternary sediment yield from the High Arctic Svalbard area. J. Geology 103, 1-17.

Faleide, J.I, Gudlaugsson, S.T., Jacquart, G., 1984. Evolution of the western Barents Sea. Mar. Petrol. Geol. 1984, 123-150.

Favier, L., Pattyn, F., Berger, S., Drews, R., 2016. Dynamic influence of pinning points on marine ice-sheet stability: a numerical study in Dronning Maud Land, East Antarctica. The Cryosphere, 10, 2623-2635.

Flink, A.E., Noormets, R., Frasner, O., Hogan, K.A., ÓRegan, M., Jakobsson, M., 2017. Past ice flow in Wahlenbergfjorden and its implications for late Quaternary ice sheet dynamics in northeastern Svalbard. Quat. Sci. Rev. 163, 162-179.

Forwick, M., Vorren, T.O., 2009. Late Weichselian and Holocene sedimentary environments and ice rafting in Isfjorden, Spitsbergen. Palaeogeogr., Palaeoclimatol., Palaeoecol. 280, 258274.

Groot, D.E., Aagaard-Sørensen, S., Husum, K., 2014. Reconstruction of Atlantic water variability during the Holocene in the western Barents Sea. Clim. Past 10, 51-62.

Hald, M., Ebbesen, H., Forwick, M., Godtliebsen, F., Khomenko, L., Korsun, S., Olsen, L.R., Vorren, T.O., 2004. Holocene paleoceanography and glacial history of the West Spitsbergen area, Euro-Arctic margin. Quat. Sci. Rev. 23, 2075-2088.

Hansen, A., Knudsen, K.L., 1995. Recent foraminiferal distribution in Freemansundet and early Holocene stratigraphy on Edgeøya, Svalbard. Polar Res. 14, 215-238.

Hogan, K.A., Dowdeswell, J.A., Noormets, R., Evans, J., Ó Cofaigh, C., 2010a. Evidence for fullglacial flow and retreat of the Late Weichselian Ice Sheet from the waters around Kong Karls Land, eastern Svalbard. Quat. Sci. Rev. 29, 3563-3582.

Hogan, K.A., Dowdeswell, J.A., Noormets, R., Evans, J., Ó Cofaigh, C., Jakobsson, M., $2010 b$. Submarine landforms and ice-flow in the Kvitøya Trough, northwestern Barents Sea. Quat. Sci. Rev. 29, 3545-3562. 
Hogan, K.A., Dowdeswell, J.A., Hillenbrand, C.-D., Ehrmann, W., Noormets, R., Wacker, L., 2017. Subglacial sediment pathways and deglacial chronology of the northern Barents Sea Ice Sheet. Boreas, doi: 10.1111/bor.12248.

Holland, D.M., Thomas, R.H., de Young, B., Ribergaard, M.H., Lyberth, B., 2008. Acceleration of Jacobshavn Isbræ triggered by warm subsurface ocean waters. Nature Geosci. 1, 659-664.

Hormes, A., Gjermundsen, E.F., Rasmussen, T.L., 2013. From mountain top to the deep sea deglaciation in 4D of the northwestern Barents Sea Ice sheet. Quat. Sci. Rev. 75, 78-99.

Howat, I.M., Joughin, I., Tulaczyk, S., Gogineni, S., 2005. Rapid retreat and acceleration of Helheim Glacier, east Greenland. Geophys. Res. Lett. 32, L22502, doi.10.1029/2005GL024737.

Jakobsson, M., Mayer L.A., Coakley B., Dowdeswell, J.A., Forbes, S., Fridman, B., Hodnesdal, H., Noormets, R., Pedersen, R., Rebesco, M., Schenke, H.W., Zarayskaya, Y., Accetella, D., Armstrong, D., Anderson, R.M., Bienhoff, P., Camerlenghi, A., Church, I., Edwards, M., Gardner, J.V., Hall, J.K., Hell, B., Hestvik, O., Kristoffersen, Y., Marcussen, C., Mohammad, R., Mosher, D., Nghiem, S.V., Pedrosa, M.T., Travaglini, P.G., Weatherall, P., 2012. The International Bathymetric Chart of the Arctic Ocean (IBCAO) Version 3.0, Geophys. Res. Lett. 39, L12609, doi: 10.1029/2012GL052219.

Jamieson, S.S.R., Vieli, A., Ó Cofaigh, C., Stokes, C.R., Livingstone, S.J., Hillenbrand, C.-D., 2014. Understanding controls on rapid ice-stream retreat during the last deglaciation of Marguerite Bay, Antarctica, using a numerical model. J. Geophys. Res. Earth Surface 119, 247-263.

Jeong, S., Howat, I.M., Bassis, J.N., 2016. Accelerated ice shelf rifting and retreat at Pine Island Glacier, West Antarctica. Geophys. Res. Lett. 43, 11,720-11,725.

Jessen, S.P., Rasmussen, T.L., Nielsen, T., Solheim, A., 2010. A new Late Weichselian and Holocene marine chronology for the western Svalbard slope 30,000 - 0 cal years BP. Quat. Sci. Rev. 29, 1301-1312.

Junek, W.N., Roman-Nieves, J.I. Woods M.T., 2014. Tectonic implications of earthquake mechanisms in Svalbard. Geophys. J. Int. 196, 1152-1161.

Kilfeather, A.A., Ó Cofaigh, C., Lloyd, J.M., Dowdeswell, J.A., Xu, S., Moreton, S.G., 2011. Icestream retreat and ice-shelf history in Marguerite Trough, Antarctic Peninsula: sedimentological and foraminiferal signatures. Geol. Soc. Am. Bull. 123, 997-1015. 
Kristensen, D.K., Rasmussen, T.L., Koc, N., 2013. Paleoceanographic changes in the northern Barents Sea during the last 16,000 years - new constraints on the last deglaciation of the Svalbard-Barents Sea Ice Sheet. Boreas 42, 798-813.

Laberg, J.S., Vorren, T.O., 1996. The glacier-fed fan at the mouth of Storfjorden trough, western Barents Sea: a comparative study. Geol. Rundschau 85, 338-349.

Lącka, M., Zajączkowski, M., Forwick, M., Szczuciński, W., 2015. Late Weichselian and Holocene paleoceanography of Storfjordrenna, southern Svalbard. Clim. Past. 11, 587-603.

Landvik, J.Y., Hjort, C., Mangerud, J., Möller, P., Salvigsen, O., 1995. The Quaternary record of eastern Svalbard - an overview. Polar Res. 14, 95-104.

Landvik, J.Y., Bondevik, S., Elverhøi, A., Fjeldskaar, W., Mangerud, J., Salvigsen, O., Siegert, M.J., Svendsen, J.I., Vorren, T.O., 1998. The last glacial maximum of Svalbard and the Barents Sea area: ice sheet extent and configuration. Quat. Sci. Rev. 17, 43-75.

Landvik, J.Y., Ingólfsson, Ó., Mienert, J., Lehman, S.J., Solheim, A., Elverhøi, A.. Ottesen, D., 2005. Rethinking Late Weichselian ice sheet dynamics in coastal NW Svalbard. Boreas 37, 7-24.

Lubinski, D.J., Polyak, L., Forman, S.L., 2001. Freshwater and Atlantic water inflows to the deep northern Barents and Kara seas since ca $13{ }^{14} \mathrm{C}$ ka: foraminifera and stable isotopes. Quat. Sci. Rev. 20, 1851-1879.

Lydersen, C., Nøst, O.A., Kovacs, K.M., Fedak, M.A., 2004. Temperature data from Norwegian and Russian waters of the northern Barents Sea collected by free-living ringed seals. J. Marine Sys. 46, 99-108.

Mangerud, J., Bondevik, S., Gulliksen, S., Hufthammer, A.K., Høisæter, T., 2006. Marine ${ }^{14} \mathrm{C}$ reservoir ages for 19th century whales and molluscs from the North Atlantic. Quat. Sci. Rev. 25, 3228-3245.

Marcott, S.A., Clark, P.U., Padman, L., Klinkhammer, G.P., Springer, S.R., Liu, Z., Otto-Bliesner, B.L., Carlson, A.E., Ungerer, A., Padman, J., He, F., Cheng, J., Schmittner, A., 2011. Iceshelf collapse from subsurface warming as a trigger for Heinrich events. PNAS 108, $13,415-13,419$.

Noormets, R., Kirchner, N., Flink A.E., 2016. Submarine medial moraines in Hambergbukta, southeastern Spitsbergen. In: Dowdeswell, J.A., Canals, M., Jakobsson, M., Todd, B.J., Dowdeswell, E.K., Hogan, K.A. (eds), Atlas of Submarine Glacial Landforms:Modern, Quaternary and Ancient. Geol. Soc. London, Mem. 46, 67-68. 
Ó Cofaigh, C., Dowdeswell, J.A., Evans, J., Larter, R.D., 2008. Geological constraints on Antarctic palaeo-ice-stream retreat. Earth Surface Processes Landforms 33, 513-525.

Ottesen, D.D., Dowdeswell, J.J., Rise, L.L., 2005. Submarine landforms and the reconstruction of fast-flowing ice streams within a large Quaternary ice sheet: the 2500-km-long NorwegianSvalbard margin $\left(57^{\circ}-80^{\circ}\right.$ N). Geol. Soc. Am. Bull. 117, 1033-1050.

Ottesen, D., Dowdeswell, J.A., Landvik, J.Y., Mienert, J., 2007. Dynamics of the Late Weichselian ice sheet on Svalbard inferred from high-resolution sea-floor morphology. Boreas 36, 286306.

Patton, H., Hubbard, A., Andreassen, K., Winsborrow, M., Stroeven, A.P., 2016. The build-up, configuration, and dynamical sensitivity of the Eurasian ice-sheet complex to Late Weichselian climatic and oceanic forcing. Quat. Sci. Rev. 153, 97-121.

Pirli, M., Schweitzer, J. and Paulsen, B., 2013. The Storfjorden, Svalbard, 2008-2012 aftershock sequence: Seismotectonics in a polar environment. Tectonophysics 601, 192-205.

Plassen, L., Rasmussen, T.L., Klitgaard Kristensen, D., Nielsen, T., Koç, N., 2008. Deglaciation history of Storfjorden, southwestern Svalbard, preliminary results. $33^{\text {rd }}$ IGC International Geological Congress, Oslo, 6-14 August 2008, Abstract no. CGC13415.

Polyak, L., Mikhailov, V., 1996. Post-glacial environments of the southeastern Barents Sea: Foraminiferal evidence. Geol. Soc. London, Spec. Publ. 111, 323-337.

Polyak, L., Solheim, A., 1994. Late- and post-glacial environments in the northern Barents Sea west of Franz Josef Land. Polar Res. 13, 97-207.

Post, A.L., Hemer, M.A., O’Brien, P.E., Roberts, D., Craven, M., 2007. History of benthic colonization beneath the Amery Ice Shelf, East Antarctica. Mar. Ecol. Progr. Ser. 344, 2937.

Quadfasel, D., Rudels, B., Kurtz, K., 1988. Outflow of dense water from a Svalbard fjord into the Fram Strait. Deep-Sea Res. A 35, 1143-1150.

Rasmussen, S.O., Andersen, K.K., Svensson, A.M., Steffensen, J.P., Vinther, B.M., Clausen, H.B., Siggaard-Andersen, M.-L., Johnsen, S.J., Larsen, L.B., Dahl-Jensen, D., Bigler, R., Röthlisberger, M., Fischer, H., Goto-Azuma, K., Hansson, M.E., Ruth, U., 2006. A new Greenland ice core chronology for the last glacial termination. J. Geophysics. Res. 111, D06102, doi:10.1029/2005JD006079. 
Rasmussen, T.L., Thomsen, E., 2004. The role of the North Atlantic Drift in the millennial timescale glacial climate fluctuations. Palaeogeogr. Palaeoclimatol., Palaeoecol. 210, 101116.

Rasmussen, T.L., Thomsen, E., 2009. Stable isotopes as signals of brines in the Barents Sea: implications for brine formation during the last glaciation. Geology 37, 903-906.

Rasmussen, T.L., Thomsen, E., 2014. Brine formation in relation to climate changes and ice retreat during the last 15,000 years in Storfjorden, Svalbard, $76-78^{\circ}$ N. Paleoceanography 29, 911-929.

Rasmussen, T.L., Thomsen, E., 2015. Paleoceanographic development in Storfjorden, Svalbard, during the deglaciation and Holocene: evidence from benthic foraminiferal records. Boreas $44,24-44$.

Rasmussen, T.L., Thomsen, E., Labeyrie, L., van Weering, T.C.E., 1996. Circulation changes in the Faeroe-Shetland Channel correlating with cold events during the last glacial period (58-10 ka). Geology 24, 937-940.

Rasmussen, T.L., Thomsen, E., Ślubowska, M.A,. Jessen, S., Solheim, A., Koç, N., 2007. Paleoceanographic evolution of the SW Svalbard margin $\left(76^{\circ} \mathrm{N}\right)$ since $20,000{ }^{14} \mathrm{C} \mathrm{yr} \mathrm{BP}$. Quat. Res. 67, 100-114.

Rasmussen, T.L., Thomsen, E., Skirbekk, K., Ślubowska-Woldengen, M., Klitgaard Kristensen, D., Koç, N., 2014. Spatial and temporal distribution of Holocene temperature maxima in the northern Nordic seas: interplay of Atlantic-, Arctic- and polar water masses. Quat. Sci. Rev. 92, 280-291.

Rebesco, M., Camerlenghi, A., llopart, J., 2016. Glacigenic debris-flow deposits, Storfjorden Fan. In: Dowdeswell, J.A., Canals, M., Jakobsson, M., Todd, B.J., Dowdeswell, E.K., Hogan, K.A. (eds), Atlas of Submarine Glacial Landforms:Modern, Quaternary and Ancient. Geol. Soc. London, Mem. 46, 373-374.

Reimer, P.J., Edouard, B., Bayliss, A., Beck, J.W., Blackwell, P.G., Ramsey, C.B., Buck, C.E., Cheng, H., Edwards, R.L., Friedrich, M., Grootes, P.M., Guilderson, T.P., Haflidason, H., Hajdas, I., Hatté, C., Heaton, T.J., Hoffmann, D.L., Hogg, A.G., Hughen, K.A., Kaiser, K.F., Kromer, B., Manning, S.W., Nju, M., Reimer, R.W., Richards, D.A., Scott, E.M., Southon, J.R., Staff, R.A., Turney, C.S.M., van der Plicht, J., 2013. INTCAL13 and Marine13 radiocarbon age calibration curves $0-50,000$ years cal BP. Radiocarbon 55, 1869-1886. 
Riddle, M.J., Craven, M., Goldsworthy, P.M., Carsey, F., 2007. A diverse benthic assemblage 100 $\mathrm{km}$ from open water under the Amery Ice shelf, Antarctica. Paleoceanography 22, PA1204, doi:10.1029/2006PA001327.

Risebrobakken, B., Moros, M., Ivanova, E.V., Chistyakova, N., Rosenberg, R., 2010. Climate and oceanographic variability in the SW Barents Sea during the Holocene. The Holocene 20, 609-621.

Rose, A., Ingels, J., Raes, M., Vanreusel, A., Arbizu, P.M., 2015. Long-term ice shelf-covered meiobenthic communities of the Antarctic continental shelf resemble those of the deep sea. Mar. Biodiv. 45, 743-762.

Shaffer, G., Olsen, S.M., Bjerrum, C.J., 2004. Ocean subsurface warming as a mechanism for coupling Dansgaard-Oeschger climate cycles and ice-rafting events. Geophys. Res. Lett. 31, L24202, doi:10.1029/2004GL020968.

Schauer, U., 1995. The release of brine-enriched shelf water from Storfjord into the Norwegian Sea. J. Geophys. Res. 100 C8, 16,015-16,028.

Skirbekk, K., Klitgaard Kristensen, D., Rasmussen, T.L., Koç, N., Forwick, M., 2010. Holocene climate variations at the entrance to a warm Arctic fjord: evidence from Kongsfjorden trough, Svalbard. Geol. Soc. London, Spec. Publ. 344, 291-306.

Ślubowska, M., Koç, N., Rasmussen, T.L., Klitgaard-Kristensen, D., 2005. Changes in the flow of Atlantic water into the Arctic Ocean since the last deglaciation: Evidence from the northern Svalbard continental margin, $80^{\circ}$ N. Paleoceanography 20, PA4014, doi:10.1029/2005PA001141.

Ślubowska-Woldengen, M., Rasmussen, T.L., Koç, N., Klitgaard-Kristensen, D., Nilsen, F., Solheim, A., 2007. Advection of Atlantic Water to the western and northern Svalbard shelves through the last $17.5 \mathrm{ka}$ cal yr BP. Quat. Sci. Rev. 26, 463-478.

Stokes, C.R., Clark, C.D., Lian, O.B., Tulaczyk, S., 2007. Ice stream sticky spots: A review of their identification and influence beneath contemporary and palaeo-ice streams. Earth-Sci. Rev. $81,217-249$.

Streuff, K., Ó Cofaigh, C., Noormets, R., Lloyd, J.M., 2017. Submarine landforms and glacimarine sedimentary processes in Lomfjorden, East Spitsbergen. Mar. Geol. 390, 51-71.

Stuiver, M., Reimer, P.J., 1993. Extended 14C database and revised CALIB radiocarbon calibration program. Radiocarbon 35, 215-230. 
940 Sugiyama, S., Sawagaki, T., Fukuda, T., Aoki, S., 2014. Active water exchange and life near the 941 942

943 Svendsen, J.I., Elverhøi, A., Mangerud, J. 1996. The retreat of the Barents Sea Ice Sheet on the 944 945

946 Svendsen, J.I., Mangerud, J., Elverhøi, A., Solheim, A., Schüttenhelm, R.T.E. 1992. The Late 947 948 Weichselian glacial maximum on western Spitsbergen inferred from offshore sediment 949 cores. Mar. Geol. 104, 1-17. 


\section{Figures:}

Fig. 1. a) The International Bathymetric Chart of the Arctic Ocean (IBCAO) Version 3.0 (Jakobsson et al. 2012) with location of the study area presented in panel b marked with red square. b) Zoom on the IBCAO map of Storfjorden, southern Svalbard with outline of the mapped area (blue line) and the seismic line shown in Fig. 4 (red line). c) Locations of seismic lines (red), Chirp lines (light grey), outline of multibeam bathymetry mapping (blue line) and gravity cores (green dots) from this study.

Fig. 2. Map of southern Svalbard showing locations of studied cores (red circles) and nearby published record referred to in the text (black circle). Abbreviations: $10=\mathrm{JM} 10-10 \mathrm{GC} ; 86=\mathrm{NP} 05-$ 86GC; 12=JM10-12GC; 1209=HH12-1209GC; 1212=HH12-1212GC; 008=HH14-008GC; 020=JM09-020GC; WSC=West Spitsbergen Current; ESC=East Spitsbergen Current; CC=Coastal Current. Map modified after Rasmussen and Thomsen (2015).

Fig. 3. Lithological logs, concentration of ice-rafted debris (IRD), concentration of benthic foraminiferal specimens, and age-depth plots marked with calibrated ages (cal years BP) for each record. For core HH14-008GC only lithological log, dates and age-depth plot are shown. Age models are shown for each core. Abbreviations: LH; late Holocene, MH; mid Holocene, EH; early Holocene, YD-H; Younger Dryas-Holocene transition, YD; Younger Dryas, AL; Allerød interstadial, BØ; Bølling interstadial. Grey bars represent sediments interpreted as till.

Fig. 4. a) North-south directed seismic line illustrating the overall seismic structure of the study area and position of coring sites. For location see Fig. 1a,c (red line). b) Seismic interpretation of the line. 
977 Fig. 5. a) Time-structure map of the Top Pre-Quaternary (TPQ) horizon that marks the top of the 978 Mesozoic or older basement in the study area. b) Time-isochore map of the total sediment thickness 979 overlaying the TPQ (basement). c-d) Time-isochore map of the glacial till deposits (unit GD) and 980 the Deglacial-Holocene deposits (unit DHD) respectively.

982 Fig. 6. Seismic lines showing cross-sections parallel (N-S) and perpendicular (E-W) to the ice flow. 983 a-b) Inner GZW; c-d) Middle GZW; e-f) Outer GZW. Location of the lines is shown in the inset 984 map.

Fig. 7. a) Sub-bottom Chirp profile showing recessional ridges of various sizes found between the middle and outer GZW. b) Interpretation of the profile. Note, that the ridges are underlain by PQ basement and covered by a thin layer of DHD sediments. Also note that while the smaller ridges are symmetric in cross-section, the two large ridges are asymmetric with a steeper flank facing north. The un-even seabed reflector is a heave artefact caused by rough sea conditions during acquisition.

Fig. 8. a) Complete multibeam bathymetry map. b-d) Zoom on the northern, central and southern study area, respectively, with marking of seabed features mentioned in the text.

Fig. 9. Interpreted ice margin positions and extent superimposed on the seismic line shown in Fig. 4 to illustrate the deglaciation history of Storfjorden - see Section 6 (Conclusion) for details. a) 
1000 Fig. 10. Map showing reconstructed ice retreat in Storfjorden indicating locations of grounding1001 zones and timing (c. 15,300 years $=$ start of Bølling interstadial; c. 14,500 years $=$ start of Allerød 1002 interstadial; c. 13,000-12,000 years $=$ Younger Dryas stadial; c. 12,000-11,700 years $=$ Younger 1003 Dryas-Holocene transition; 11,600 years = start of Holocene interglacial). Solid lines are based on 1004 seismic data in combination with calibrated AMS- ${ }^{14} \mathrm{C}$ dates from core records, hatched lines are 1005 suggested positions. Northward pointing arrow indicates a possible retreat during Allerød 1006 interstadial, southward pointing indicates a possible advance during the Younger Dryas. Red 1007 arrows indicate inflow of sub surface warm Atlantic water.

1009 Tables:

1010 Table 1. Locations of studied cores

1011 Table 2. AMS ${ }^{14} \mathrm{C}$ dates and calibrated ages for cores HH14-008GC and HH12-1212GC 1012 


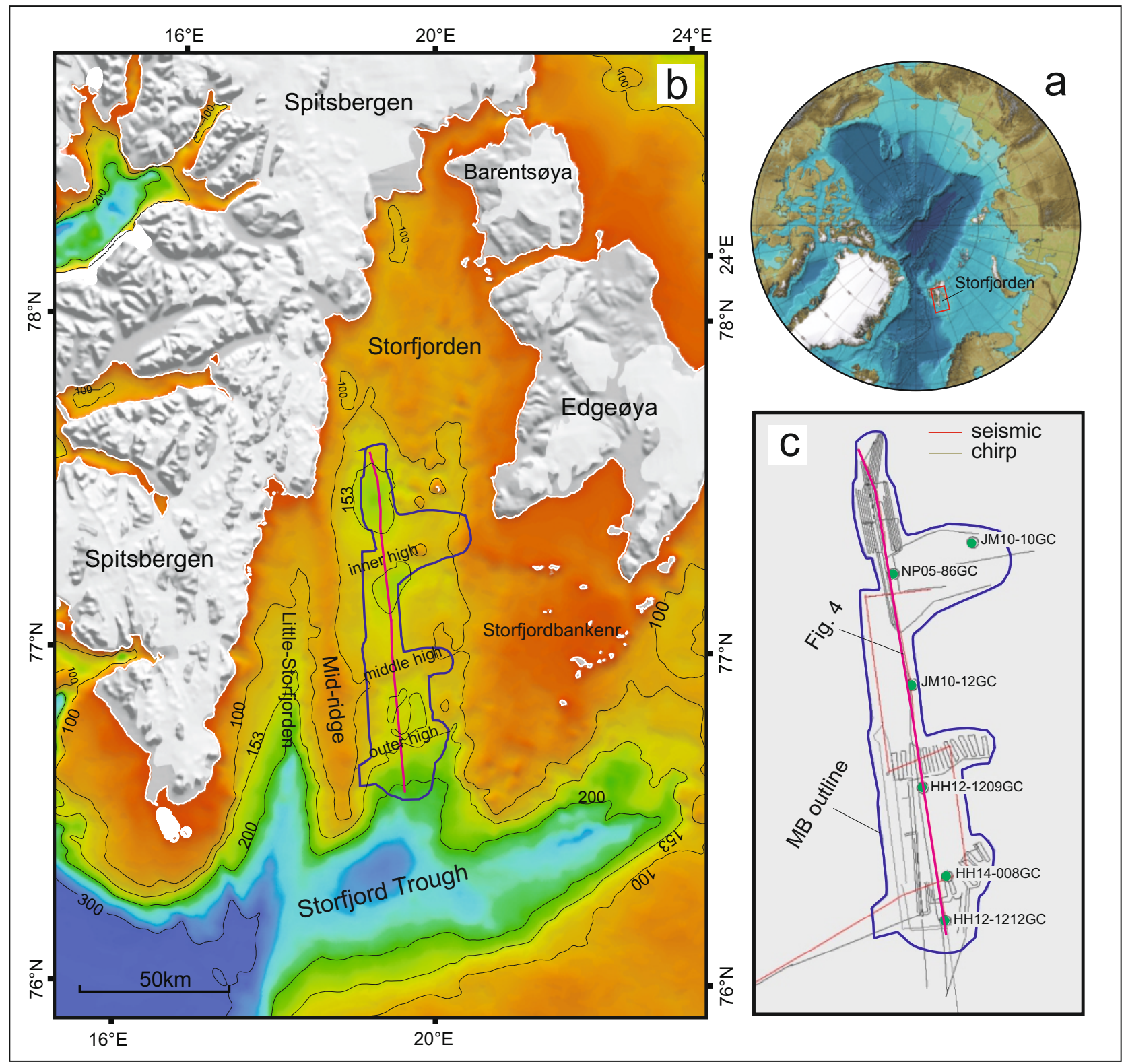




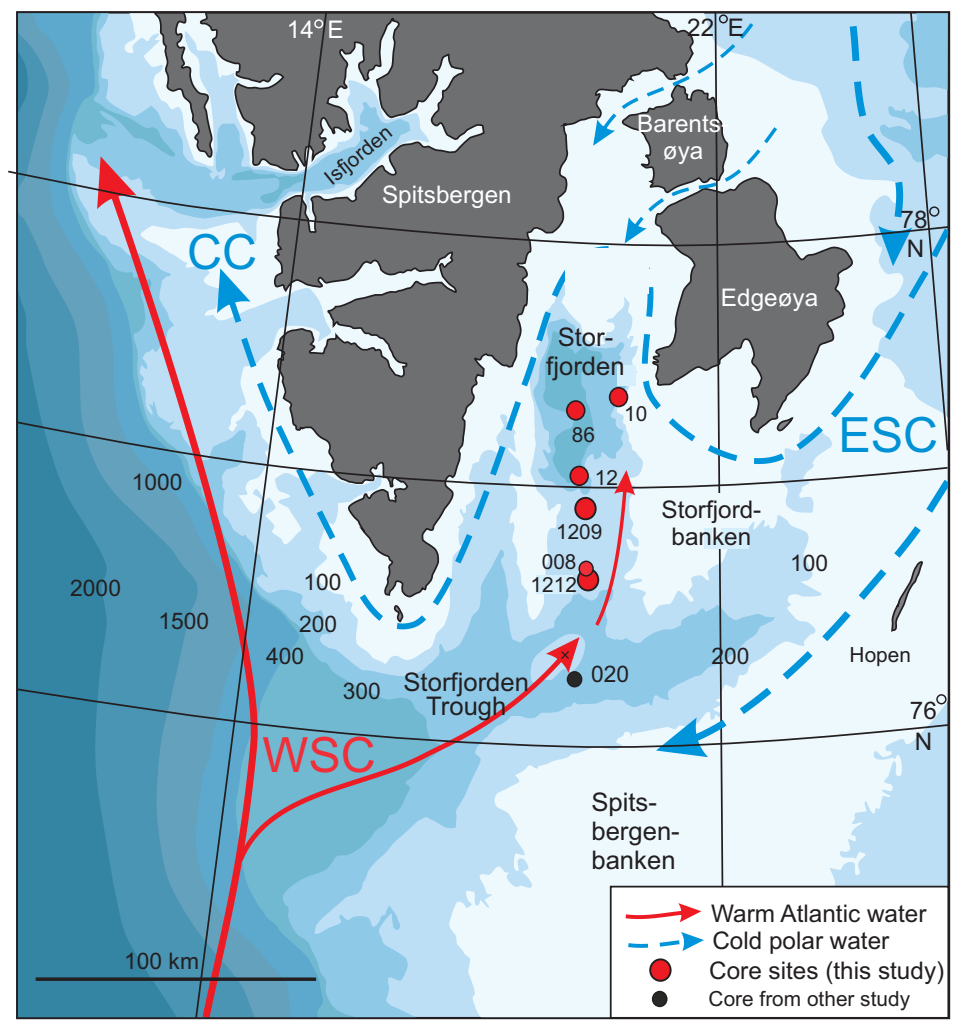




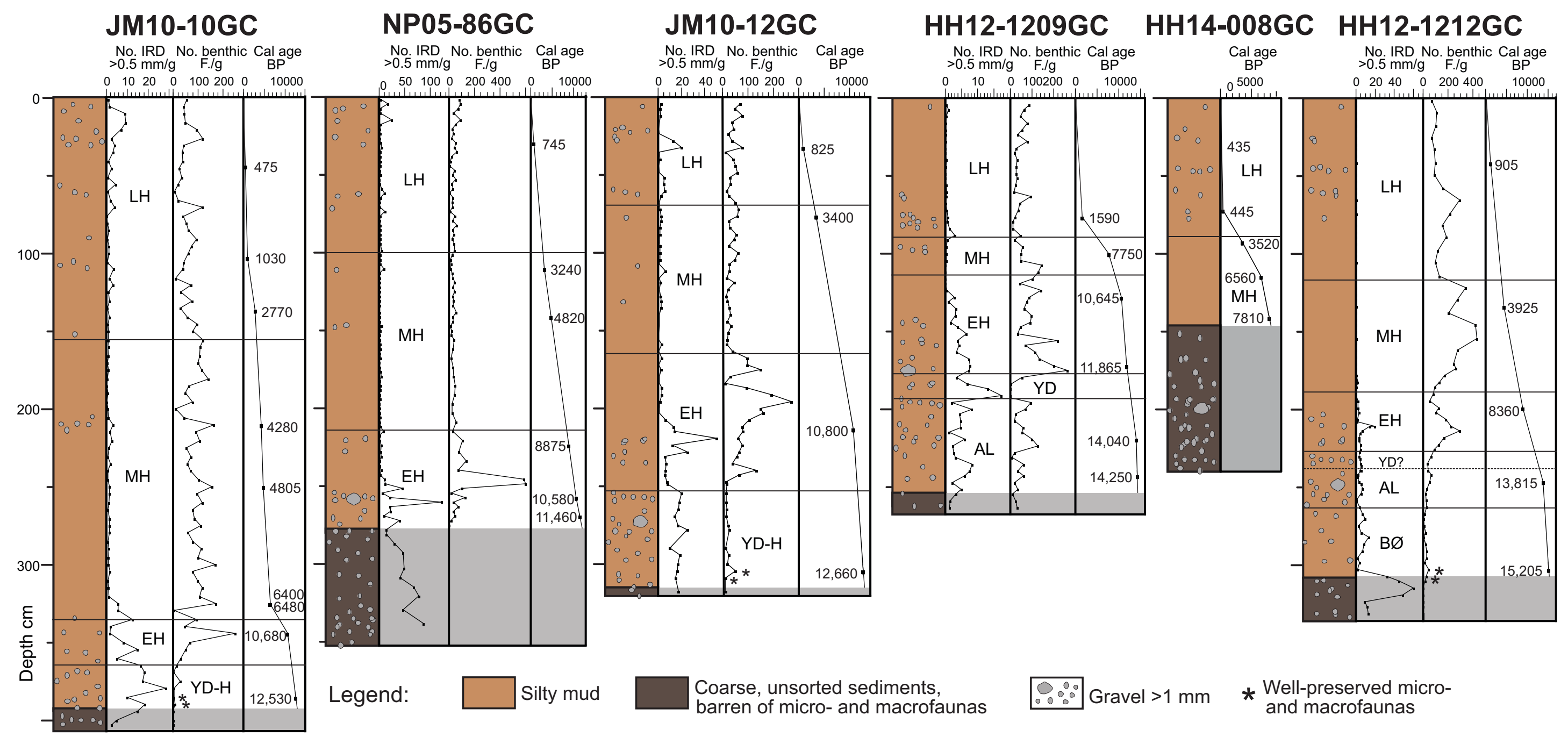


a

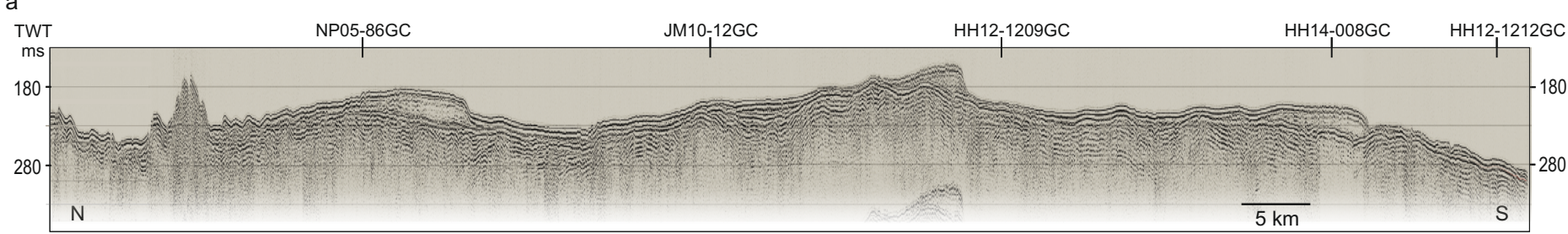

b

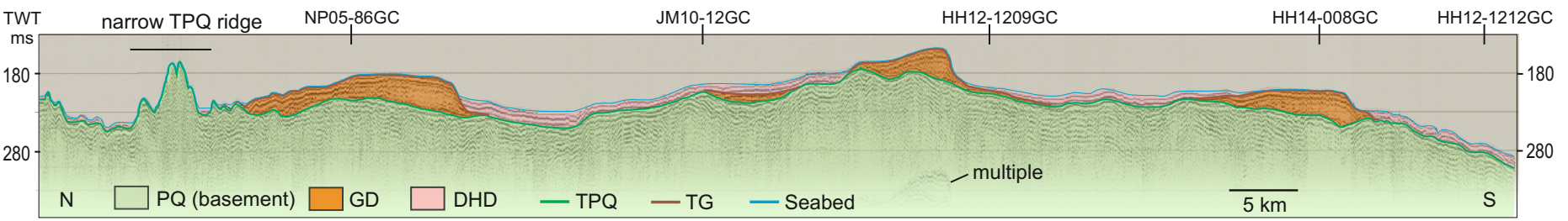




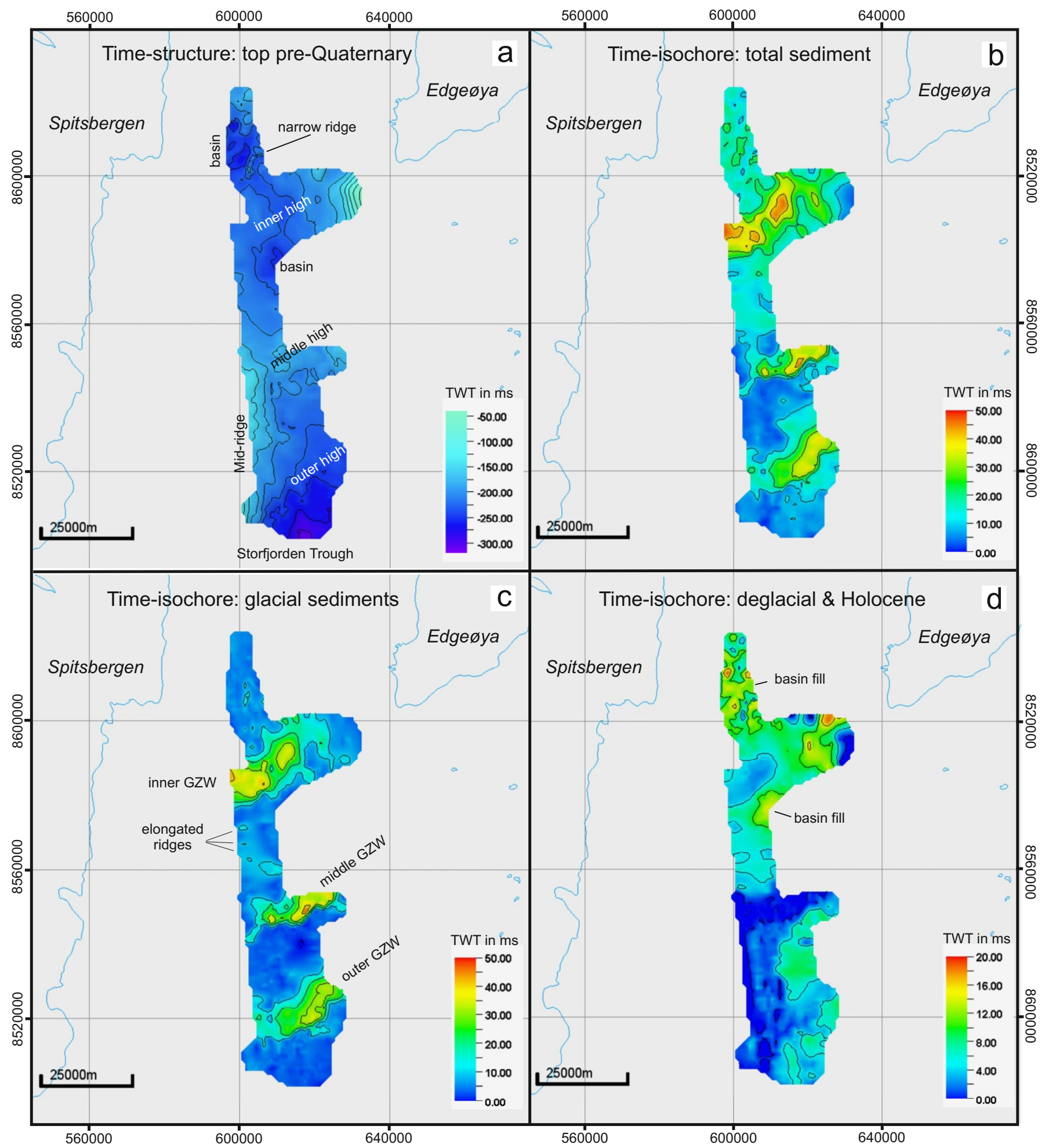



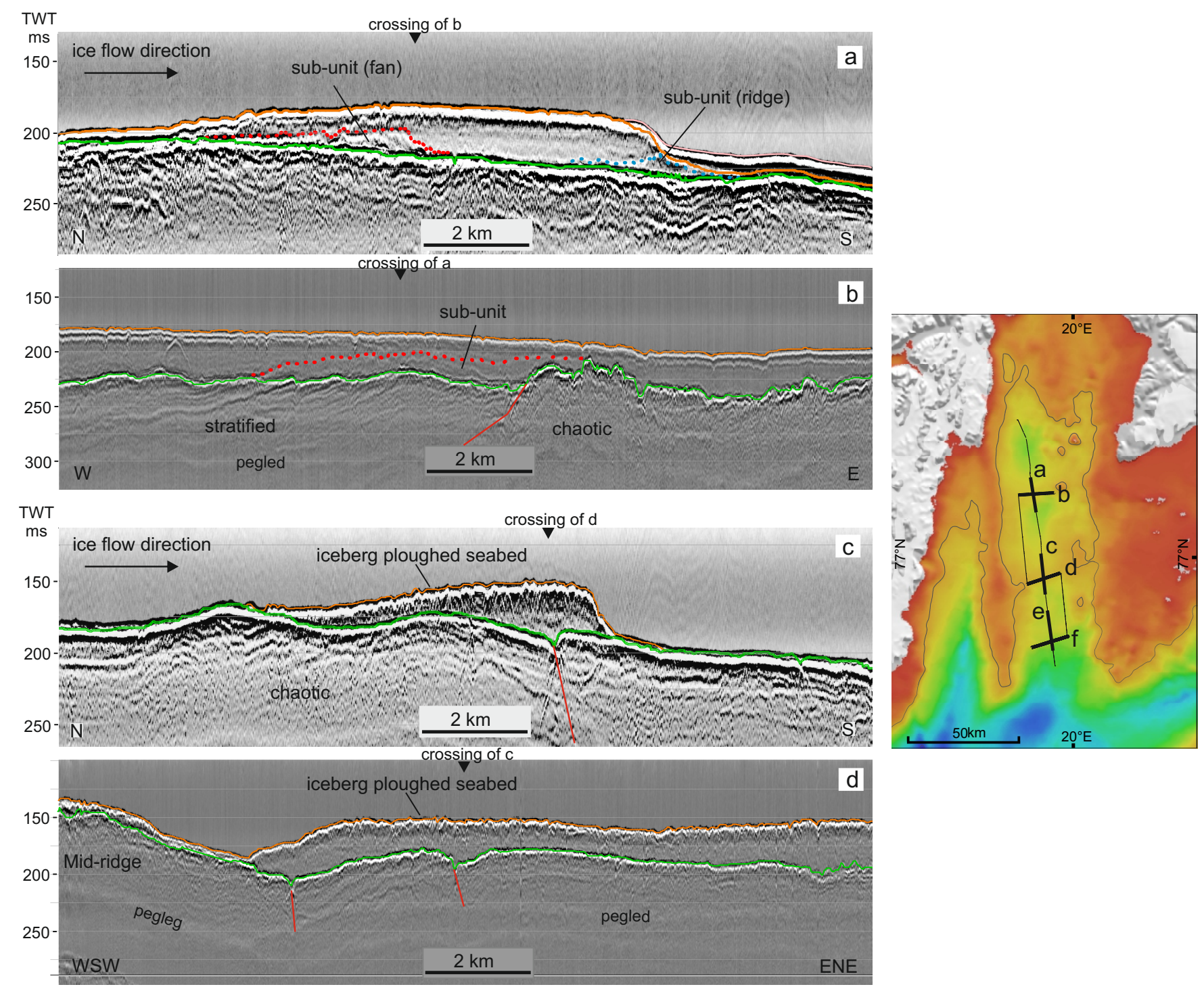

d

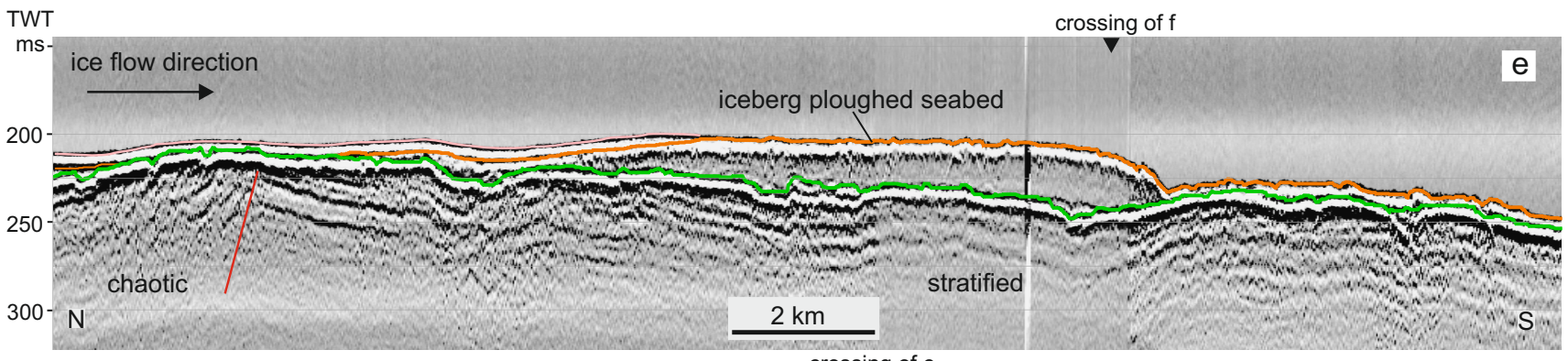

crossing of e

200 iceberg ploughed seabed

250

300

chaotic stratified

WSW 


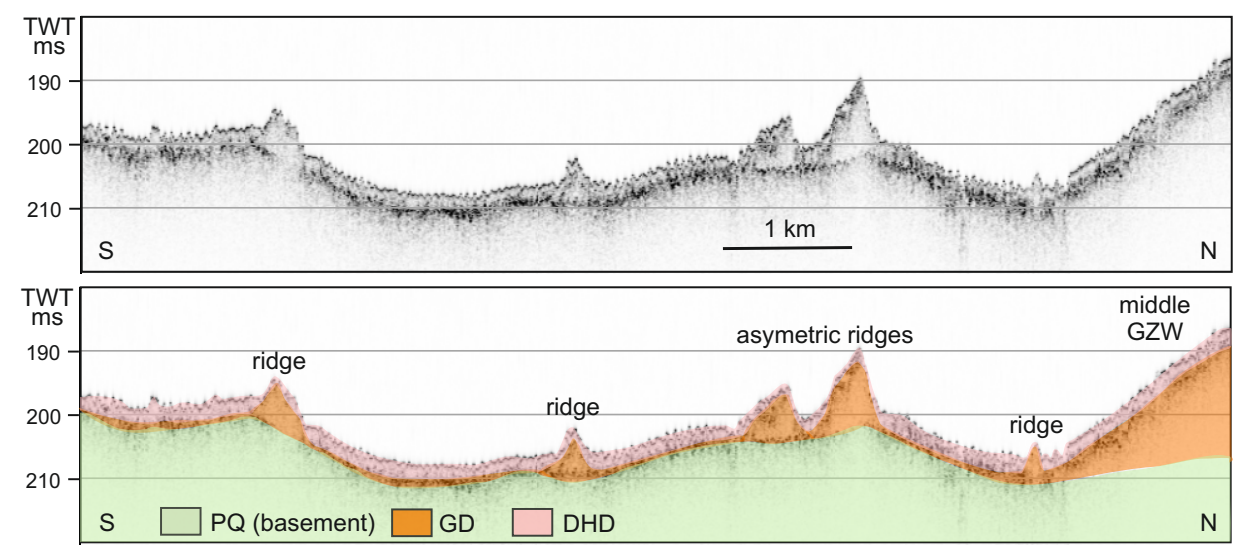



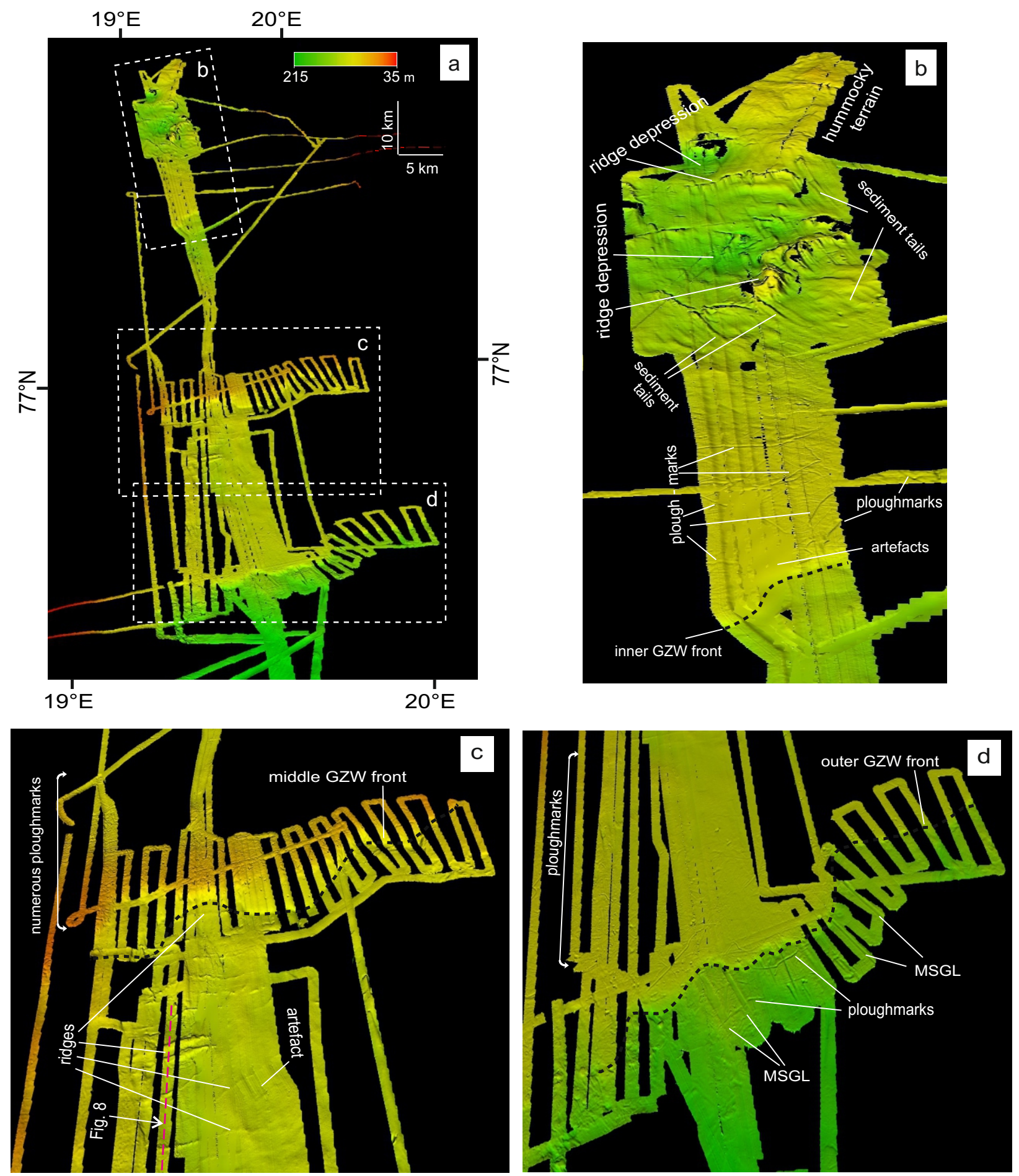


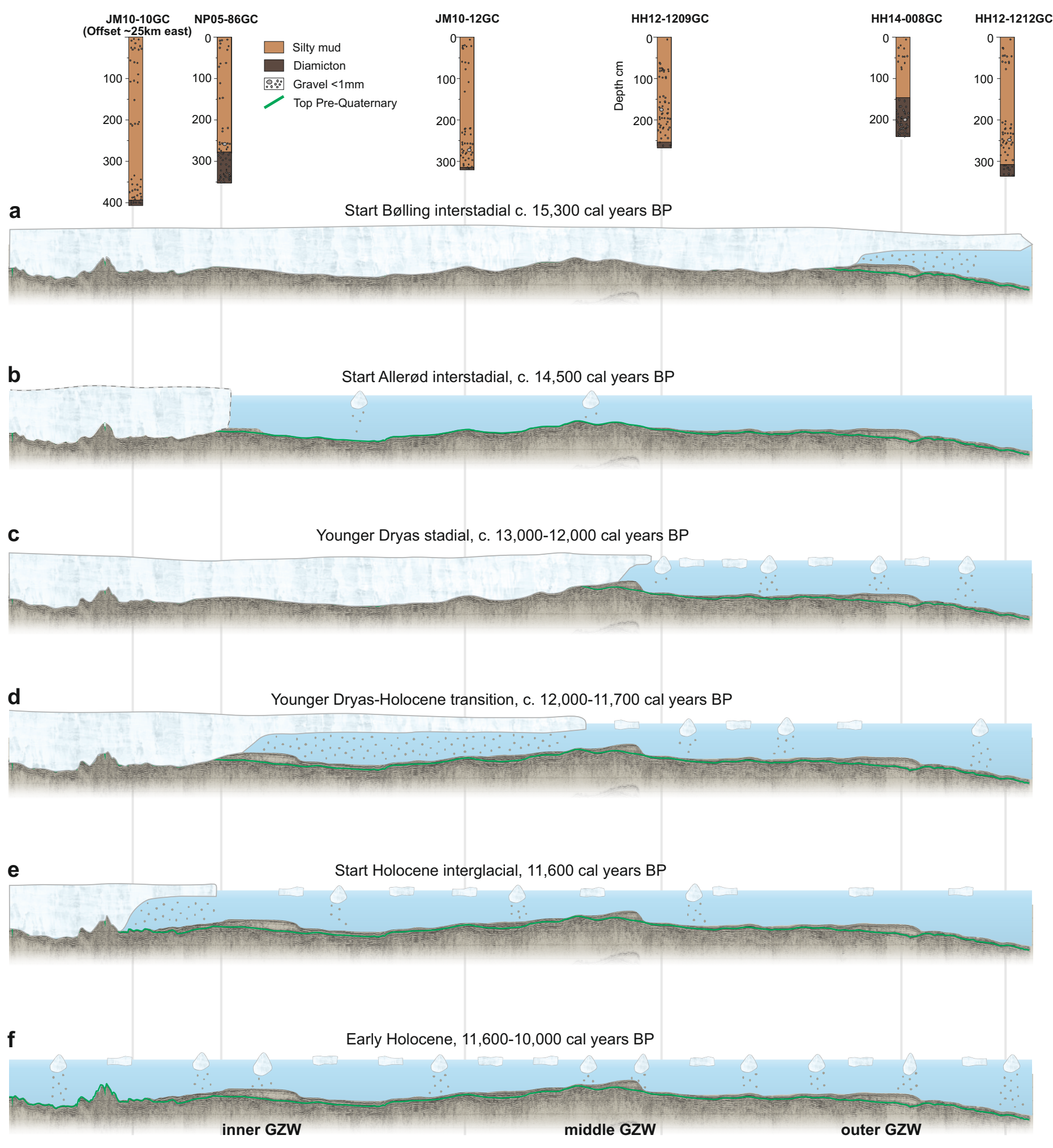




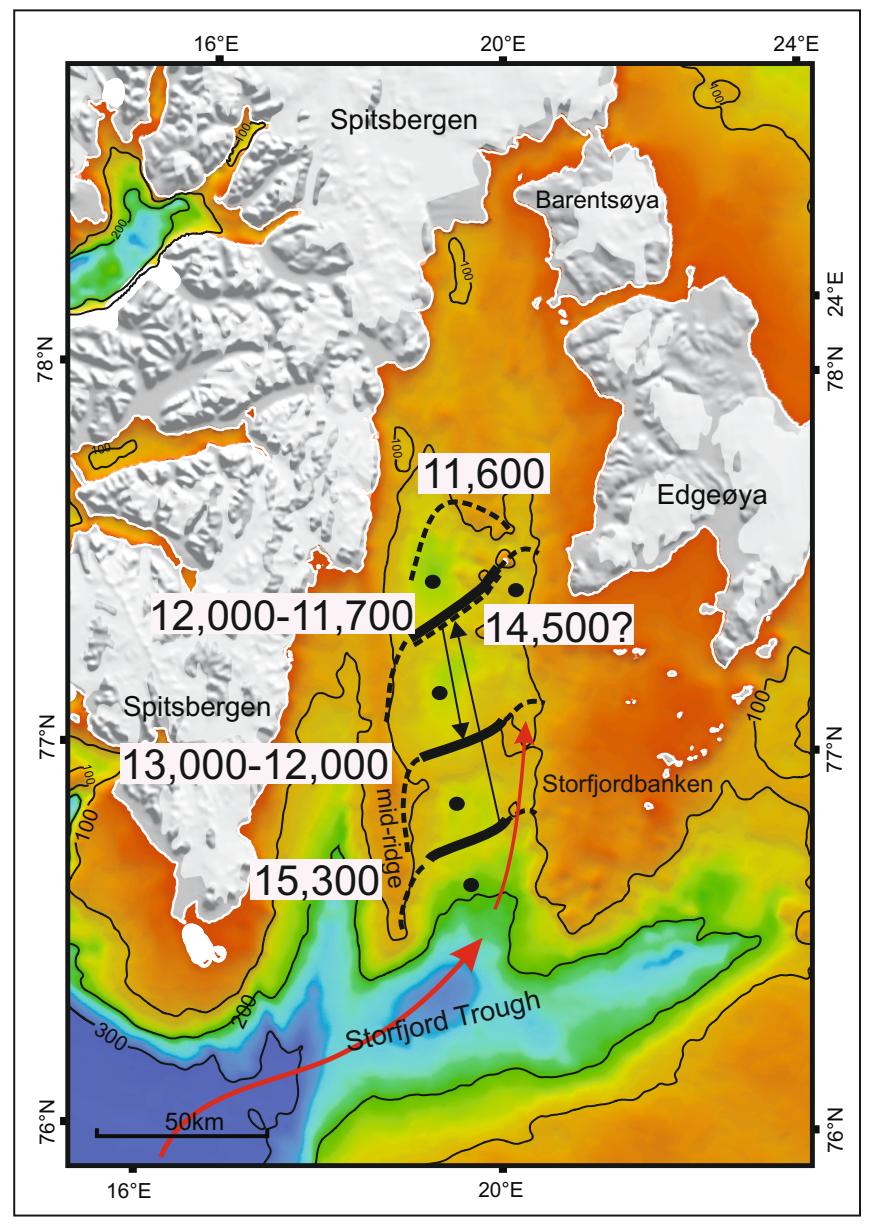


Table 1. Positions and water depth of studied cores

\begin{tabular}{lccccl}
\hline \multicolumn{1}{c}{ Core } & Latitude & Longitude & Water depth $(\mathrm{m})$ & Cruise & References \\
\hline NP05-86GC: & $77^{\circ} 21.60^{\prime}$ & $019^{\circ} 18.46^{\prime}$ & 141 & RV Lance, 2005 & Plassen et al., 2008 \\
JM10-10GC: & $77^{\circ} 24.812^{\prime}$ & $020^{\circ} 05.972$ & 123 & RV Jan Mayen, 2010 & Rasmussen and Thomsen, 2014 \\
JM10-12GC: & $77^{\circ} 07.358^{\prime}$ & $019^{\circ} 24.459^{\prime}$ & 146 & RV Jan Mayen, 2010 & Rasmussen and Thomsen, 2014 \\
HH12-1209GC & $76^{\circ} 54.178^{\prime}$ & $019^{\circ} 26.068$ & 151 & RV Helmer Hanssen, 2012 & Rasmussen and Thomsen, 2014 \\
HH14-008GC & $76^{\circ} 42.675^{\prime}$ & $019^{\circ} 35.834^{\prime}$ & 159 & RV Helmer Hanssen, 2014 & This study \\
HH12-1212GC & $76^{\circ} 37.011^{\prime}$ & $019^{\circ} 32.906^{\prime}$ & 178 & RV Helmer Hanssen, 2014 & This study \\
\hline
\end{tabular}


Table 1. $\mathrm{AMS}^{14} \mathrm{C}$ dates and calibrated ages for cores HH14-008GC and HH12-1212GC

\begin{tabular}{|c|c|c|c|c|c|}
\hline Core & Depth cm & ${ }^{14} \mathrm{C}-$ age $^{\mathrm{a}}$ & Calender age & Lab. Code & Species \\
\hline \multirow[t]{5}{*}{ HH14-008GC } & 28.5 & $783 \pm 31$ & $435 \pm 37$ & UB-27266 & Astarte sp. \\
\hline & 72.0 & $791 \pm 27$ & $445 \pm 30$ & UB-27267 & Astarte sp. \\
\hline & 92.5 & $3625 \pm 29$ & $3520 \pm 45$ & UB-27268 & Astarte sp. \\
\hline & $113-115$ & $6129 \pm 41$ & $6560 \pm 58$ & UB-27269 & Astarte sp. \\
\hline & $140-143$ & $7348 \pm 34$ & $7810 \pm 50$ & UB-27853 & Bivalves \\
\hline \multirow[t]{7}{*}{ HH12-1212GC } & 41.5 & $1352 \pm 25$ & $905 \pm 33$ & UB24648 & Portlandia arctica \\
\hline & 132.5 & $3944 \pm 28$ & $3925 \pm 49$ & UB24649 & Nucula sp. \\
\hline & 196.5 & $7899 \pm 38$ & $8360 \pm 35$ & UB24651 & Portlandia fragment \\
\hline & 241.5 & Failed & & UB-24652 & N. labradorica \\
\hline & 245.0 & $12,340 \pm 57$ & $13,815 \pm 82$ & UB-25132 & Bryozoans \\
\hline & 300.5 & Failed & & UB-25611 & Elphidium excavatum \\
\hline & $299-303$ & $13,171 \pm 49$ & $15,205 \pm 74$ & UB-28381 & Micro- and macrofossils* \\
\hline
\end{tabular}

*E. excavatum, C. reniforme, small remains of bryozoans, molluscs and ophiurians 